C2017, Elsevier. Licensed under the Creative Commons Attribution-NonCommercialNoDerivatives 4.0 International http://creativecommons.org/about/downloads (c) 


\title{
Occurrence, Fate and Transformation of Emerging Contaminants in Water: An Overarching Review of the Field
}

\author{
John Wilkinson ${ }^{1,2 *}$, Peter S. Hooda ${ }^{1}$, James Barker ${ }^{3}$, Stephen Barton ${ }^{3}$ and Julian Swinden ${ }^{3}$ \\ ${ }^{1}$ Kingston University London, School of Natural and Built Environments, Kingston-Upon-Thames, U.K. \\ ${ }^{2}$ University of York, Environment Department, York, UK \\ ${ }^{3}$ Kingston University London, School of Life Sciences, Pharmacy and Chemistry, Kingston-Upon-Thames, U.K. \\ *Corresponding author, University of York, Environment Department, York, U.K., email: \\ john.wilkinson@york.ac.uk
}

\begin{abstract}
Many of the products and drugs used commonly contain chemical components which may persist through sewage treatment works (STW) and eventually enter the aquatic environment as parent compounds, metabolites, or transformation products. Pharmaceuticals and personal care products (PPCPs) and other emerging contaminants (ECs) have been detected in waters (typically $\mathrm{ng} / \mathrm{L}$ ) as well as more recently bound to sediment and plastic particles (typically $\mathrm{ng} / \mathrm{g}$ ). Despite significant advancement of knowledge since the late 1990s, the fate of these contaminants/transformation products once introduced into the aquatic environment remains relatively unresolved.

This review provides a unique focus on the fate of seven major groups of PPCPs/ECs in the aquatic environment, which is frequently not found in similar works which are often compound or topic-specific and limited in background knowledge. Key findings include: a) some replacements for regulation precluded/banned chemicals may be similarly persistent in the environment as those they replace, b) the adsorption of potentially bioactive chemicals to micro- and nanoplastics is a significant topic with risks to aquatic organisms potentially greater than previously thought, and c) micro-/nanoplastics are likely to remain of significant concern for centuries after regulatory limitations on their use become active due to the slow degradation of macro-plastics into smaller components.

An interdisciplinary perspective on recent advances in the field is presented here in a unique way which highlights both the principle science and direction of research needed to elucidate the fate and transport patterns of aquatic PPCPS/ECs. Unlike similar reviews, which are often topic-specific, here we aim to present an overarching review of the field with focus on the occurrence, transformation and fate of emerging contaminants. Environmental presence of seven major classes of contaminants (analygesics, antibiotics, antineoplastics, beta-blockers, perfluorinated compounds, personal care products and plasticisers), factors affecting contaminant fate, association with plastic micro/nanoparticles and photochemical transformation are comprehensively evaluated.
\end{abstract}

Acknowledgments: Kingston University London is thankfully acknowledged for funding this work.

Keywords: Pharmaceuticals and personal care products; emerging contaminants; microplastics; photochemical transformation; aquatic pollutants; emerging contaminant fate 


\section{Table of Contents}

Abstract

1.0 Introduction

2.0 The Profile of PPCP Contamination: What's in the Water?

$2.1 \quad$ Analgesics

$2.2 \quad$ Antibiotics

2.3 Antineoplastic Compounds (ACs)

$2.4 \quad$ Beta-Blockers

2.5 Perfluorinated Compounds (PFCs)

2.6 Personal Care Products (PFCs)

2.7 Plasticisers

3.0 Environmental Transport and Fate of PPCP and other ECs

3.1 Atmospheric Transportation and Precipitation

3.2 Adsorption to Sediment and Suspended Solids

3.3 Biodegradation of Organic Contaminants

3.4 Photochemical Transformation

3.4.1 Direct Photochemical Transformation

3.4.2 Indirect Photochemical Transformation

3.4.3 Photochemical Transformation of PPCPs/ECs in the Aquatic Environment

3.5 PPCP/ECs in Sewage Biosolids used as Agricultural Additives

3.6 Temporal and Seasonal effects on PPCP and EC Loading

3.7 Micro- and Nanoplastics in the Aquatic Environment

3.7.1 Significant legislation regulating the manufacture, sale and import of products containing plastic particles

4.0 Conclusions and Direction for Research

5.0 References 


\section{List of Tables}

Table 1: Comparison of influent and effluent concentrations of 10 commonly reported pharmaceuticals in sewage and wastewater

Table 2: Amounts (in tonnes) of several common pharmaceuticals consumed annually

Table 3: Proportion of the parent compound excreted for 60 common pharmaceuticals

Table 4: Concentration ranges of 42 commonly detected pharmaceuticals, personal care products and other emerging contaminants in surface water (adapted from Wilkinson et al., 2016a)

Table 5: Concentrations of 14 PPCP and other ECs in surface water, suspended solids, and sediment

Table 6: Summary of significant regulation set on the sale, manufacture and import of products containing plastic microparticles across the world as of early 2017

\section{List of Figures}

Figure 1: Sources and fate of PPCP and other ECs in the aquatic environment 


\subsection{Introduction and background of the field}

Pharmaceuticals, personal care products (PPCPs), and many other synthetic organic compounds have revolutionised modern life and their use is now an indispensable component of a healthy society. Pharmaceutical use in particular is an integral component of establishing and maintaining a healthy population of both humans and livestock. In recent years, PPCPs and other emerging contaminants (ECs) have been detected in sewage effluents, surface- and ground-waters, precipitation, and occasionally drinking waters at trace levels (Ternes, 1998; Mohle et al., 1999; Stackelberg et al., 2004; Thomas and Hilton, 2004; Weigel et al., 2004; Lindqvist et al., 2005; Fent et al., 2006; Jjemba et al., 2006; Nikolaou et al., 2007; Kasprzyk-Hordern et al., 2008; Benotti and Brownawell, 2009; Mahmoud et al., 2009; Silva et al., 2011; Lopez-Serna et al., 2013; Tijani et al., 2016). Furthermore, these compounds are also shown to be present in suspended solids and river sediment (McClellan and Halden, 2010; Walters et al., 2010; Silva et al., 2011; Wilkinson et al., 2017).

The seemingly ubiquitous environmental presence of pharmaceuticals and other socalled 'emerging contaminants', albeit in trace or ultra-trace (below $\mathrm{ng} / \mathrm{L}$ ) concentrations, has become of great concern in recent years (Tijani et al., 2016). Furthermore, the extent of PPCPs and other ECs found in the environment, as well as their often largely unknown transformation products, is virtually limitless as new drugs and replacements for regulatory limited compounds are continually being introduced to market.

Many pharmaceuticals and personal care products contain complex chemical structures, often in combination. The original source of these products can be traced to respective manufacturing plants (e.g., 3303 tonnes of paracetamol were produced in France in 2008). However, after leaving manufacturing plants, their routes of environmental exposure become more complex, less understood, and differ between urban and rural environments (Figure 1). Every human represents a source of PPCP and other emerging contamination, particularly with increasing use of pharmaceuticals (Table 2). From use of soaps and plastics to prescription and non-prescription pharmaceuticals, the personal care products and pharmaceuticals we use in everyday life will inevitably enter the environment after use and excretion. Un-used pharmaceuticals, disposed of in toilets or drains, as well as partially or un-metabolised medication excretions by humans have been shown to be a significant source of prescription and non-prescription drug contamination, representing up to $90 \%$ of input (National Association of Clean Water Agencies, 2012). Olsen et al. (2009) found urine to be the most significant source of PPCP elimination in humans. Pharmaceuticals are often not completely metabolised in the body resulting in some proportion of the parent compound (or conjugated derivative) entering sewage treatment facilities (Table 3) via renal (urine) and biliary (faeces) excretions then introduced into the environment (by STW effluent) after incomplete degradation (Jjemba, 2006; Silva et al., 2011).

Virtually every human and veterinary pharmaceutical, either prescription or nonprescription, has been detected in sewage treatment works (STW) effluent (Table 1) and the aquatic environment at levels typically not exceeding upper $\mathrm{ng} / \mathrm{L}$. Personal care product (PCP) contamination often includes residues of surfactants used in detergents and soaps, plasticisers used in product packaging and linings, musk compounds used as fragrances, personal insecticides, disinfectants, among others. So-called other ECs include noncommonly monitored agricultural chemicals (for example many herbicides, pesticides and 
pharmaceuticals used in animal husbandry) and even residues of recreational drugs and their metabolites (Rosi-Marshall et al., 2015). Recent concern regarding groundwater/aquifer contamination by chemicals used in the hydraulic fracturing of shale (e.g., naphthalene used as a surfactant and tetramethyl ammonium chloride as clay stabiliser) may be considered novel emerging contaminants (Gordalla et al., 2013).

Once in the aquatic environment, other than some well-researched compounds (e.g., BPA and ethinylestradiol), their ultimate fate (i.e., bioaccumulation, spatial distribution, and partition between dissolved and bound to suspended particulate material phases) in aquatic ecosystems is relatively unclear. Most reviews on the study of ECs tend to be limited to a certain chemical (e.g. BPA: Corrales et al., 2015), group of chemicals (e.g. endocrine disrupting compounds: Patisaul and Adewale, 2009; Fisher and Eugster, 2014) or on certain specific aspects of PPCPs/ECs (e.g. removal/degradation during sewage treatment: Luo et al., 2014). This review critically examines the most influential research, encompassing seven major groups of PPCPs and ECs, with a particular focus on occurrence, association with micro-/nanoplastic particles, and bio- and photochemical transformation.

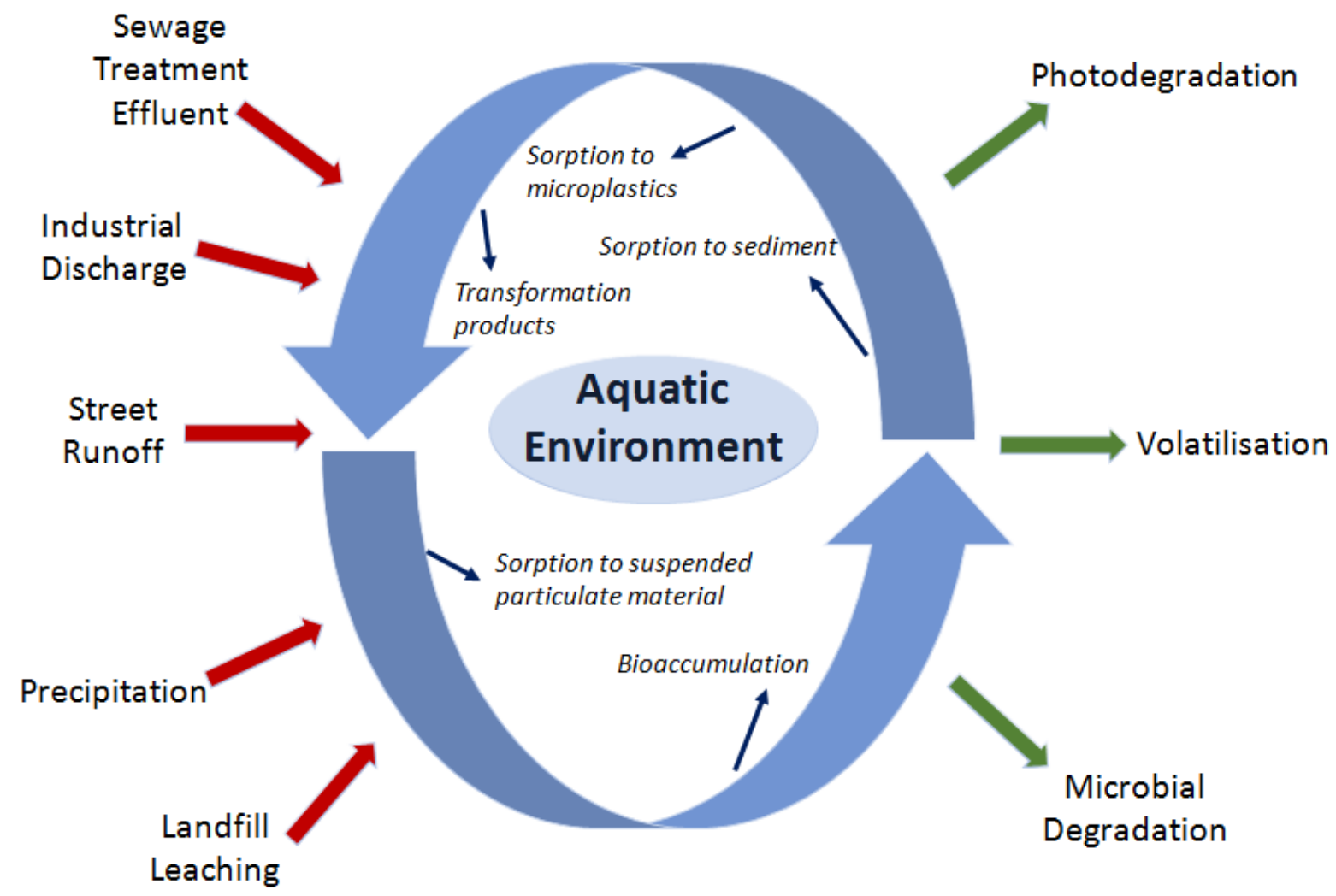

Figure 1. Sources and fate of PPCP and other ECs in the aquatic environment. 
Table 1. Comparison of influent and effluent concentrations of 10 commonly reported pharmaceuticals in wastewater

\begin{tabular}{|c|c|c|c|}
\hline Compound & STW Influent (ng/L) & STW Effluent (ng/L) & Source \\
\hline \multirow[t]{2}{*}{ Atenolol } & $1250^{*}$ & $800 *$ & Jelic et al. (2011) \\
\hline & 795 & 330 & Vieno et al. (2007) \\
\hline \multirow[t]{2}{*}{ Bezafibrate } & $800 *$ & $400 *$ & Jelic et al. (2011) \\
\hline & 4700 & 600 & Metcalfe et al. (2003) \\
\hline \multirow[t]{2}{*}{ Carbamazepine } & $1050^{*}$ & $750 *$ & Jelic et al. (2011) \\
\hline & 1900 & $2300 * *$ & Metcalfe et al. (2003) \\
\hline \multirow[t]{2}{*}{ Diclofenac } & $1550^{*}$ & $900 *$ & Jelic et al. (2011) \\
\hline & 1300 & ND & Metcalfe et al. (2003) \\
\hline \multirow[t]{2}{*}{ Gemfibrozil } & $170^{*}$ & $420 * *$ & Jelic et al. (2011) \\
\hline & 2100 & 1300 & Metcalfe et al. (2003) \\
\hline Ibuprofen & 8600 & 510 & Guerra et al. (2014) \\
\hline \multirow[t]{2}{*}{ Ketoprofen } & $2650 *$ & $800 *$ & Jelic et al. (2011) \\
\hline & 5700 & ND & Metcalfe et al. (2003) \\
\hline \multirow[t]{2}{*}{ Metoprolol } & $130 *$ & $80 *$ & Jelic et al. (2011) \\
\hline & 1060 & 755 & Vieno et al. (2007) \\
\hline
\end{tabular}

\subsection{The profile of PPCP Contamination: What's in the Water?}

Since the use of synthetic compounds such as pharmaceuticals and personal care products started, these contaminants have been present in the natural and built environments (Jelić, 2012). More than 80 compounds and several metabolites have been found in the aquatic environment and some in drinking water, which indicates that not all contaminants are removed during water treatment (Heberer, 2002). While their presence is not a new phenomenon, noticeable attention has been drawn to them within the last decade (Jelić, 2012). Arguably much of this novel interest is due to recent research into the ecotoxicological effects on aquatic organisms of other synthetic compounds such as herbicides and pesticides. Product proliferation and ease of access to pharmaceuticals and personal care products have significantly increased the loading of such compounds in both the natural and built environments (National Association of Clean Water Agencies, 2012). The exact combination of compounds in sources of water varies from location to location and concentrations are consistently higher in ground and surface water than in drinking water (Benotti and Brownawell, 2009; National Association of Clean Water Agencies, 2012).

Worldwide, few such compounds have been inventoried or regulated as contaminants (Caliman and Gavrilescu, 2009). Thus, a lack of knowledge exists regarding the occurrence, proliferation, impacts and fate of synthetic pharmaceuticals and personal care products in the environment (Caliman and Gavrilescu, 2009). Benotti and Brownawell (2009) found 21 different synthetic compounds in 19 different municipal water supplies in the United States. In this study, 51 pharmaceuticals were tested for, of which nearly half were detected (Benotti and Brownawell, 2009). The ten most commonly found pharmaceutical contaminants were: atenolol, estrone, carbamazepine, meprobamate, gemfibrozil, naproxen, phenytoin, sulfamethoxazole, trimethoprim, and TCEP (Benotti and Brownawell, 
2009). Of the ten most commonly found, median concentrations were less than $10 \mu \mathrm{g} / \mathrm{L}$ (Benotti and Brownawell, 2009). While such concentrations may seem low, some compounds (e.g., ethinylestradiol) have been shown to be endocrine disruptors during critical periods of biological development in fish at concentrations as low as $\leq 1 \mathrm{ng} / \mathrm{L}$ (Parrott and Blunt, 2005; Baumann et al., 2014). Thus, particularly in terms of hormonal disruption, concentrations of synthetic contaminants can have biological effects at concentrations detected in environmental samples.

In the United Kingdom, Jones et al. (2002) modelled aquatic concentrations of the 25 most frequently used pharmaceuticals in the nation. Compounds ranged from sodium valproate, an anti-epileptic drug, to ibuprofen, an analgesic (Jones et al., 2002). Surface water concentrations of all contaminants were modelled with conservative estimates and exceeded $1 \mathrm{ng} / \mathrm{L}$ (Jones et al., 2002). Some of the most commonly used drugs in the United States alone are asthma medication for children, central nervous system stimulants, antidepressants, and cholesterol lowering medication, all of which have been detected in US waters (Centers for Disease Control, 2010). In 2000, the U.S. Geological Survey (USGS) began one of the first and perhaps still most significant reconnaissance studies of the 95 most common PPCPs in the United States focusing on 136 different streams and rivers running through intensive livestock production and urban centres (Barnes et al., 2002; Kolpin et al., 2002). During the study, 82 of the 95 PPCPs were detected (Kolpin et al., 2002). While concentrations were generally low and did not often surpass U.S. drinking water guidelines (where guidelines exist for such contaminants), known endocrine disrupting compounds were discovered at physiologically active concentrations (Kolpin et al., 2002). Furthermore, mixtures of PPCPs present in water were common as a median of 7 contaminants and as many as 38 were found in individual streams or rivers bringing to light possible combination/synergistic effects (Kolpin et al., 2002). In recent years, research has commonly focused on elucidating the presence, concentrations, and at times spatial distribution of such contaminants in the aquatic environment (Musolff et al., 2009; Sánchez-Avila et al., 2010; Al Aukidy et al., 2012; Li, 2014). Such research serves to indicate that contamination of the aquatic environment with synthetic compounds is a worldwide phenomenon. Several commonly reported classes of PPCPs have been observed and are discussed in greater detail within this chapter. Table 4 shows concentrations of 42 commonly detected PPCP/ECs in surface, ground and drinking water of five different countries.

\subsection{Analgesics}

Non-Steroidal Anti-inflammatory Drugs such as ibuprofen, paracetamol (acetaminophen), naproxen, and diclofenac are commonly used and relatively easily accessible. Prior to STW discharge, ibuprofen appears to be readily degraded into its two main metabolites: carboxyibuprofen and hydroxyibuprofen. Concentrations of parent-ibuprofen have been found at levels up to $24600 \mathrm{ng} / \mathrm{L}$ (4000 $\mathrm{ng} / \mathrm{L}$ median) in STW effluents and at levels of 700 $\mathrm{ng} / \mathrm{L}$ in seawater (Metcalfe et al., 2003; Weigel et al., 2004). While paracetamol appears to be well removed during sewage treatment, Kolpin et al. (2002) identified levels of the parent compound of paracetamol at median levels of $110 \mathrm{ng} / \mathrm{L}$ in $24 \%$ of sampled U.S. streams and rivers. Other analgesics, such as codeine, were found in the same study at median levels of $10 \mathrm{ng} / \mathrm{L}$ in $7 \%$ of sampled streams and rivers. Analgesics such as naproxen, ibuprofen and paracetamol have also been detected in rivers and canals of Spain at levels of $81 \mathrm{ng} / \mathrm{L}, 470 \mathrm{ng} / \mathrm{L}$ and $40 \mu \mathrm{g} / \mathrm{L}$ respectively (Al Aukidy et al., 2012; Li, 2014). In six Canadian STWs, Guerra et al. (2014) identified acetaminophen, ibuprofen, hydroxyibuprofen and 
naproxen at respective median levels of $92000 \mathrm{ng} / \mathrm{L}, 8600 \mathrm{ng} / \mathrm{L}, 24000 \mathrm{ng} / \mathrm{L}$ and $6280 \mathrm{ng} / \mathrm{L}$ in all collected influent samples and $2200 \mathrm{ng} / \mathrm{L}, 510 \mathrm{ng} / \mathrm{L}, 4200 \mathrm{ng} / \mathrm{L}$ and $580 \mathrm{ng} / \mathrm{L}$ in 58\%, 92\%, $67 \%$ and $100 \%$ of respective effluent samples. In the same study, acetaminophen, ibuprofen, 2-hydroxy-ibuprofen and naproxen were extracted from biosolids collected in the same sewage treatment facilities at respective median levels of $23 \mathrm{ng} / \mathrm{g}$ dry weight (dw) biosolid, $150 \mathrm{ng} / \mathrm{g} \mathrm{dw}, 79 \mathrm{ng} / \mathrm{g} \mathrm{dw}$ and $24 \mathrm{ng} / \mathrm{g} \mathrm{dw}$ in 25\%, 100\%, 13\% and 75\% of collected samples (Guerra et al., 2014). Environmental levels of common analgesics appear relatively constant over recent years with median levels of naproxen and ibuprofen reported at 550 $\mathrm{ng} / \mathrm{L}$ and $200 \mathrm{ng} / \mathrm{L}$ respectively in rivers and canals of both New Jersey and Canada (Li, 2014).

\subsection{Antibiotics}

Antibiotics are one of the oldest, most successful, and most commonly used classes of pharmaceuticals. Both human and veterinary antibiotics are commonly found in the aquatic environment (Baquero et al., 2008; Kümmerer, 2009; Martinez, 2009; Jiang, 2013; Berglund, 2014). In addition to parent compounds, metabolites of antibiotics such as erythromycin and penicillin (e.g., penicilloic acid) have also been detected at levels, up to $30 \mathrm{ng} / \mathrm{L}$ in both ground and surface waters (Focazio et al., 2008). Sulphonamides sulfamethoxazole and sulfapyridine have been found in Spanish STW effluents at levels up to $18 \mathrm{ng} / \mathrm{L}$ and $28 \mathrm{ng} / \mathrm{L}$ as well as their acetylated metabolites at $9 \mathrm{ng} / \mathrm{L}$ and $52 \mathrm{ng} / \mathrm{L}$ respectively (Garcia-Galan et al., 2012). Kolpin et al. (2002) found residues of several common antibiotic contaminants in US streams and rivers (see Table 4) including triclosan at $2300 \mathrm{ng} / \mathrm{L}$. Trimethoprim and sulfamethoxazole have also been detected at levels of $2 \mathrm{ng} / \mathrm{L}$ and $46 \mathrm{ng} / \mathrm{L}$ respectively in Canadian groundwater (Van Stempvoort et al., 2013), $6 \mathrm{ng} / \mathrm{L}$ and $3 \mathrm{ng} / \mathrm{L}$ respectively in rivers and canals of Spain (Li, 2014), and $2000 \mathrm{ng} / \mathrm{L}$ and $39 \mathrm{ng} / \mathrm{L}$ respectively in STW effluent in Taiwan (Li, 2014). Despite the typically low concentration of such compounds, their occurrence in the aquatic environment is suggested to influence the development of antibiotic resistance in microorganisms (Hong et al., 2013; Berglund, 2014). However, such findings are debated and warrant further investigation.

\subsection{Antineoplastic Compounds (ACs)}

Antineoplastic (anticancer) pharmaceutical contamination of the aquatic environment is of concern as their use continues to increase (Brezovsek et al., 2014). Several compounds used in chemotherapy have been identified in hospital wastewater, surface waters, STW facilities, and even estuarine waters (Thomas and Hilton, 2004; Roberts and Thomas, 2006; Fent et al., 2006). Among those identified include, ifosfamide, daunorubicin etoposide and methotrexate at concentrations of $<2-10647 \mathrm{ng} / \mathrm{L},<5-380 \mathrm{ng} / \mathrm{L}$ and $<2-4689 \mathrm{ng} / \mathrm{L}$ respectively in hospital wastewater (Yin et al., 2010). In the UK, tamoxifen, a drug used in the treatment of breast cancer, was identified by Roberts and Thomas (2006) at levels ranging between 146 and $369 \mathrm{ng} / \mathrm{L}$ in STW effluents. Furthermore, levels of the same drug were identified in the Tyne estuary (Tyne and Wear, UK) at levels of 27-212 ng/L, indicating a strong environmental persistence and likely low degradation in STW facilities (Thomas and Hilton, 2004; Roberts and Thomas, 2006). Antineoplastic compounds appear to be incompletely removed by sewage treatment and not readily biodegradable (Besse et al., 2012). Liu et al. (2010) show maximum STW influent and effluent levels of anastrozole of $0.32 \mathrm{ng} / \mathrm{L}$ and $0.30 \mathrm{ng} / \mathrm{L}$ respectively indicating the compound is poorly removed from 
Chinese STW. Surface water concentrations of antineoplastic compounds are typically low and have been reported up to $64.8 \mathrm{ng} / \mathrm{L}$ for cyclophosphamide (Moldovan, 2006), $0.14 \mathrm{ng} / \mathrm{L}$ for ifosfamide (Buerge et al., 2006), and $25 \mathrm{ng} / \mathrm{L}$ for tamoxifen (Coetsier et al., 2009). Zounkova et al. (2010) suggest some antineoplastic compounds may be found in hospital effluents at biologically significant concentrations to common aquatic bacteria however it should be noted that such biologically significant levels are currently not well-established or researched.

\subsection{Beta-Blockers}

Beta-blockers, or beta-adrenergic receptor antagonists, are used for the treatment of high blood pressure and heart attack recovery and have been identified in sewage and surface waters (Fent et al., 2006; Maurer et al., 2007). Such compounds commonly include sotalol, atenolol, metoprolol, propranolol, and bisoprolol. Atenolol and metoprolol have been identified at highest levels of up to $33100 \mathrm{ng} / \mathrm{L}$ and $1520 \mathrm{ng} / \mathrm{L}$ respectively in STW influent and $7600 \mathrm{ng} / \mathrm{L}$ and $250 \mathrm{ng} / \mathrm{L}$ respectively in STW effluents (Luo et al., 2014). Beta-blockers appear to be relatively degradable in STW facilities showing removal efficiencies from $56.4 \%$ for metoprolol to $85.1 \%$ for atenolol, for example (Maurer et al., 2007; Luo et al., 2014). Atenolol has been reported in multiple countries including in the ground water of France up to $30 \mathrm{ng} / \mathrm{L}$ (Vulliet and Cren-Olivé., 2011), Korea up to $690 \mathrm{ng} / \mathrm{L}$ (Kim et al., 2009), and the United Kingdom up to $680 \mathrm{ng} / \mathrm{L}$ (Kasprzyk-Hordern et al., 2009).

\subsection{Perfluorinated Compounds}

Perflourinated compounds (PFCs) are characterised by a fluorinated carbon chain of variable length and are commonly used as anti-stick or water repellent liners for clothing, packaging, automobiles, among other uses. PFCs include compounds such as perfluorooctanoic acid (PFOA), used in fluoropolymers such as Teflon, and perfluorooctane sulfonate (PFOS), a fluorosurfactant used in stain repellents and fire-fighting foams. Other PFCs may be used in cosmetics and hydrophobic coatings, such as used with some clothing items (Inoue et al., 2004). Research has shown these compounds frequently detected in the environment, even being found in deep arctic seas (Rudel et al., 2003; Skutlarek et al., 2006; Farré et al., 2008; Jahan et al., 2008; Arvaniti et al., 2015; Wilkinson et al., 2017). Perfluorinated compounds are not limited to the aquatic environment. PFOA and PFOS have been consistently detected in the vacuum cleaner dust of Japanese homes at levels up to $3700 \mathrm{ng} / \mathrm{g}$ and $2500 \mathrm{ng} / \mathrm{g}$ respectively (Moriwaki et al., 2003). In addition, Fluorotelomer alcohols (FTOHs), such as 8:2 $\mathrm{FTOH}$, have been detected in Japanese precipitation at concentrations up to $1.97 \mathrm{ng} / \mathrm{L}$ indicating the atmosphere as both a medium of transport and source of contamination (Mahmoud et al., 2009). Fluorotelomer alcohols are common precursors to many fluorosurfactants, a component of many personal care products and are so too used in the production of stain repellents and hydrophobic product coatings.

Typically, PFCs are found in rivers at levels below $100 \mathrm{ng} / \mathrm{L}$ but PFOA has been identified in the Moehne River, Germany, at up to $3640 \mathrm{ng} / \mathrm{L}$ and perfluoropentanoic acid up to $1638 \mathrm{ng} / \mathrm{L}$ (Skutlarek et al., 2006). PFCs including PFOS, PFOA, and perfluorononanoic acid (PFNA) have been detected in port and coastal sea water at concentrations typically not exceeding $0.75 \mathrm{ng} / \mathrm{L}$ but have been detected by Sánchez-Avila et al. (2010) up to $8.38 \mathrm{ng} / \mathrm{L}$ (PFOS) in port seawater and $3.93 \mathrm{ng} / \mathrm{L}$ (PFOS) in coastal seawater. Recent evidence suggests levels of PFCs may be elevated in street water runoff during periods of rainfall where levels 
of PFNA and PFOA have been reported as high as 648 and $1160 \mathrm{ng} / \mathrm{L}$ respectively in areas of heavy transport vehicle activity (Wilkinson et al., 2016b). Many PFCs are, at times, detected at higher concentrations in river water than in STW effluent water indicating their sources may not always be predominately wastewater-driven (Sánchez-Avila et al., 2010). Zushi and Masunaga (2009) suggest that concentrations of PFCs in rivers are highest in areas receiving runoff from heavy transportation land use (in particular near train stations). Thus, land use may be associated with the introduction of PFCs to rivers via runoff (rainfall-driven) events.

Table 2. Amounts (in tonnes) of twelve common pharmaceuticals consumed annually

\begin{tabular}{|c|c|c|c|c|c|c|}
\hline \multirow[b]{2}{*}{ Drug Class } & \multirow[b]{2}{*}{$\begin{array}{l}\text { Compound } \\
\text { (in Tonnes) }\end{array}$} & \multicolumn{5}{|c|}{ Country, (Year), [Population] } \\
\hline & & $\begin{array}{c}\text { England }^{1} \\
(2000) \\
{[58,789,194]}\end{array}$ & $\begin{array}{c}\text { Germany }^{2} \\
(2001) \\
{[82,350,000]} \\
\end{array}$ & $\begin{array}{c}\text { France }^{3} \\
(2008) \\
{[64,370,000]}\end{array}$ & $\begin{array}{c}\text { Germany }^{4,5} \\
(2010) \\
{[81,780,000]}\end{array}$ & $\begin{array}{c}\text { Spain }^{5} \\
(2010) \\
{[47,020,000]}\end{array}$ \\
\hline \multirow[t]{4}{*}{ Analgesic } & Diclofenac & 26.12 & 85.8 & 22.64 & 78.58 & 17.4 \\
\hline & Ibuprofen & 162.2 & 344.89 & 58.35 & 250.79 & 218.53 \\
\hline & Naproxen & 35.07 & $\mathrm{n} / \mathrm{a}$ & 37.33 & $\mathrm{n} / \mathrm{a}$ & 56.7 \\
\hline & Paracetamol & 390.9 & 621.65 & 3303.08 & $\mathrm{n} / \mathrm{a}$ & 1065.84 \\
\hline Antacid & Ranitidine & 36.32 & 85.81 & $\mathrm{n} / \mathrm{a}$ & $\mathrm{n} / \mathrm{a}$ & $\mathrm{n} / \mathrm{a}$ \\
\hline \multirow[t]{2}{*}{ Antibiotic } & Amoxicillin & $\mathrm{n} / \mathrm{a}$ & $\mathrm{n} / \mathrm{a}$ & 333.22 & $\mathrm{n} / \mathrm{a}$ & 187.76 \\
\hline & Clarithromycin & $\mathrm{n} / \mathrm{a}$ & $\mathrm{n} / \mathrm{a}$ & 16.89 & 12.36 & 10.86 \\
\hline Anticonvulsant & Carbamazepine & 40.35 & 87.6 & 33.36 & 83.3 & 20.95 \\
\hline Antidiabetic & Metformin & 205.8 & 516.91 & $\mathrm{n} / \mathrm{a}$ & $\mathrm{n} / \mathrm{a}$ & $\mathrm{n} / \mathrm{a}$ \\
\hline \multirow[t]{2}{*}{$\beta$-Blocker } & Atenolol & 28.98 & $\mathrm{n} / \mathrm{a}$ & $\mathrm{n} / \mathrm{a}$ & $\mathrm{n} / \mathrm{a}$ & $\mathrm{n} / \mathrm{a}$ \\
\hline & Metoprolol & $\mathrm{n} / \mathrm{a}$ & 92.97 & $\mathrm{n} / \mathrm{a}$ & $\mathrm{n} / \mathrm{a}$ & $\mathrm{n} / \mathrm{a}$ \\
\hline Lipid lowering & Bezafibrate & $\mathrm{n} / \mathrm{a}$ & $\mathrm{n} / \mathrm{a}$ & 20.85 & 39.16 & 6.25 \\
\hline & \multirow{2}{*}{$\begin{array}{l}{ }^{1} \text { Jones et al. } \\
(2002) \\
{ }^{4} \text { ter Laak., } \\
(2010)\end{array}$} & & \multicolumn{2}{|c|}{${ }^{2}$ Huschek et al. (2004) } & \multicolumn{2}{|c|}{$\begin{array}{l}{ }^{3} \text { Vulliet and Cren-Olivé, } \\
\text { (2011) }\end{array}$} \\
\hline & & & \multicolumn{2}{|c|}{${ }^{5}$ Ortez de Garcia et al. (2013) } & \multicolumn{2}{|c|}{ *n/a, not available } \\
\hline
\end{tabular}

Drinking water treatment does not appear to be an absolute barrier to PFCs. Zafeiraki et al. (2015) quantified concentration of 11 PFCs in treated drinking water and found $\Sigma$ PFCs up to $54 \mathrm{ng} / \mathrm{L}$ in $48.6 \%$ of tested waters near Amsterdam, Netherlands. Here, short-chain PFCs such as perfluoropentanoic acid and perfluorohexanoic acid were detected more frequently than long chain (C>8) PFCs, particularly in areas using purified surface water over groundwater (Zafeiraki et al., 2015).

PFCs, and their metabolites are shown to be persistent and bioaccumulative in the aquatic environment and not easily degraded by microbiological or chemical treatment in sewage and drinking water treatment (Skutarek et al., 2006; Arvaniti et al., 2015). Schultz (2006) showed that mass flow of 6:2 fluorotelomer sulfonate and perfluorooctanoate remained unchanged through STW trickling filtration and primary clarification. Mass flow of perfluorooctane and perfluorodecane sulfonates increased during trickling filtration and activated sludge treatment due to degradation of their precursor molecules, mainly fluorotelomer alcohols (Schultz et al., 2006). Many PFCs appear to be metabolised to their sulfonate and carboxylic acid metabolites (Farré et al., 2008). 
In recent years, many long-chain (>C7) carboxylic and sulfonic acid PFCs (e.g., perfluorooctanoic acid- PFOA) have been replaced by shorter, less bioaccumulative derivatives (Sun et al., 2016). However, resent evidence suggests that new generation shortchain replacements such as perfluoro-2-propoxypropanoic acid (which has replaced PFOA for many uses) are similarly persistent through wastewater treatment and found at concentrations exceeding those of long-chain 'legacy' PFCs $630 \mathrm{ng} / \mathrm{L}$ in river water (Sun et al., 2016). Similarly, Wilkinson et al. (2017) quantified concentrations of short chain replacement perfluorobutanesulfonic acid between 1.4 to 1.7-fold higher than long-chain alternatives in sewage treatment effluent and receiving water bodies of southern England. While study indicates that long-chain PFCs may be highly persistent and bio-/accumulative in the aquatic environment (Sun et al., 2016), future research should focus on determining the environmental fate and accumulation of short-chain alternatives to traditional $(>C 7)$ PFCs. While no clear and significant statutory regulation of long-chain PFCs exists, government bodies have encouraged use of short-chain analogues through programmes such as the US EPA's PFOA Stewardship Programme and the Stockholm Convention's Persistent Organic Review Committee's guidance on replacements for PFOS. Ultimately, the use and manufacture of long-chain PFCs has been phased out of most OECD countries with some production shifted to other locations (Stockholm Convention on Persistent Organic Pollutants, 2010). Additionally, over 150 potential short-chain and other chemical replacements for PFOA alone have been established under the EPA's PFOA Stewardship Programme (United States Environmental Protection Agency, 2017).

\subsection{Personal Care Products (PCPs)}

Common PCPs include fragrances (musk compounds), UV filters (sunscreens), detergents, lotions, personal insecticides, deodorants, and cleaning products which are typically released through household wastewater (Peck, 2006; Roosens et al., 2007). Cleaning products used in domestic and industrial applications (detergents and soaps) can include non-ionic surfactants such as alkylphenol ethoxylates (AEOs), of which more than $90 \%$ are nonylphenol ethoxylates (NPEOs) (Farré et al., 2008). Compounds of interest include 4'nonylphenol, a well-known metabolite of NPEOs which has recently been detected up to 80 $\mathrm{ng} / \mathrm{L}$ in the Vaal River, South Africa (Chokwe et al., 2015).

Synthetic Musk Compounds (SMCs) are commonly used in personal care products and are widely occurring in the environment with varying chemical structures (Roosens et al., 2007; Lee I. et al., 2010). These compounds were first developed the end of the $19^{\text {th }}$ century and have since been continually produced for fragrance in cosmetics, soaps, perfumes, detergents and lotions (Lee I. et al., 2010). Some of the most commonly occurring SMCs include Tonalide (AHTN), Galaxolide (HHCB), musk xylene (MX), and musk ketone (MK) and have been detected in PCPs such as lotions, perfumes, and deodorants at levels up to $8000 \mu \mathrm{g} / \mathrm{g}, 22000 \mu \mathrm{g} / \mathrm{g} 26 \mu \mathrm{g} / \mathrm{g}$, and $0.5 \mu \mathrm{g} / \mathrm{g}$ respectively (Roosens et al., 2007). Typically, SMCs occur in Sewage treatment works (STW) influent at levels of 3690-7330 $\mathrm{ng} / \mathrm{L}$, effluent at levels of 960-2960 ng/L, and surface water at 150-16700 ng/L (Lee I. et al., 2010).

Ultraviolet (UV) filters, such as benzophenone-4 (BP-4) and 2-Phenylbenzimidazole5 -sulphonic acid (PBSA), have only relatively recently been reported in STW influent, effluent, surface- and at times in drinking-waters (Giokas et al., 2007; Kasprkyz-Hordern et al., 2008; Rodil et al., 2008; 2012). Residues of UV filters are thought to be largely seasonally introduced through bathing and other recreational use of water (Rodil et al., 2012). In 
northwest Spain, Rodil et al. (2012) detected BP-4 and PBSA in all sampled STW influents at median concentrations of $2100 \mathrm{ng} / \mathrm{L}$ and $200 \mathrm{ng} / \mathrm{L}$ respectively. Similarly, median concentrations of $1200 \mathrm{ng} / \mathrm{L} \mathrm{BP}-4$ and $240 \mathrm{ng} / \mathrm{L}$ PBSA were found in treated STW effluent and up to $600 \mathrm{ng} / \mathrm{L} \mathrm{BP}-4$ and $20 \mathrm{ng} / \mathrm{L}$ PBSA in surface water (Rodil et al., 2012). Among UV filters detected in drinking water (frequency between $12-46 \%$ of samples) concentrations are typically below $10 \mathrm{ng} / \mathrm{L}$ except BP-4, which has been detected up to $60 \mathrm{ng} / \mathrm{L}$ in northwest Spain (Rodil et al., 2012).

The implications of such PCPs in the aquatic environment is somewhat unclear when compared to the relatively large amount of research conducted elucidating the aquatic toxicity of human pharmaceuticals (Brausch and Rand, 2011). Toxicity of trace-level (ng/L to low $\mu \mathrm{g} / \mathrm{L}$ ) PCPs in the aquatic environment are highly debated and are reviewed in greater detail elsewhere (e.g., Brausch and Rand, 2011). Further research is warranted particularly in assessing potential endocrine disruption associated with exposure to UV-filters and bioaccumulation of PCPs in the aquatic environment (Brausch and Rand, 2011).

\subsection{Plasticisers}

Plasticisers are compounds which increase the plasticity of a material and are often involved in the production of plastic products/packaging, epoxy resins (coating cans for food and beverage), water pipe lining, thermal printing paper, implanted medical devices and in the production of CDs and DVDs, mobile phones, plastic food containers, eye glass lenses, drinking bottles, food packaging, dental sealants, among many others (Barraza, 2013; American Dental Association, 2016; Testai et al., 2016). Common plasticisers found in surface water include bisphenol-A (BPA), bisphenol-S (BPS), and bisphenol-F (BPF) which have recently been detected up to $98 \mathrm{ng} / \mathrm{L}, 135 \mathrm{ng} / \mathrm{L}$, and $1110 \mathrm{ng} / \mathrm{L}$ respectively in the Pearl River, China (Yamazaki et al., 2015). Bisphenol-A has also been detected at levels of up to 50 $\mathrm{ng} / \mathrm{L}$ (average of $<9 \mathrm{ng} / \mathrm{L}$ ) in $<5 \%$ of 291 sampled tap waters across France (Colin et al., 2014). BPA in particular is made at one of the highest volumes of any PPCP in the world with more than 2 million metric tonnes produced annually (Lang et al., 2008; Maia et al., 2009). Despite government restrictions being placed on BPA use, the market for BPA, and hence the compound's production, is poised for continued growth (see a comprehensive market analysis of BPA use and production: Merchant Research and Consulting, 2015). In 2011, in response to widespread concern over safety in the public and scientific sectors, the European Commission restricted the use of BPA as a monomer in the manufacture of polycarbonates (Grignard et al., 2012). However, since 2011, worldwide production of BPA has increased $5.25 \%$ annually showing total production of 4.4 million tonnes in 2011, 4.6 million tonnes in 2012 and 5.4 million tonnes in 2015 (Merchant Research and Consulting, 2015). Approximately 53\% of BPA is produced in Asia with major centres of production in Taiwan, South Korea, China and Japan (Merchant Research and Consulting, 2015).

In response to concern over environmental toxicity of BPA and the compound's widespread use in thermal printer paper, the USEPA released a report outlining 19 possible replacements for BPA (most other plasticisers) and their associated toxicity (USEPA, 2014). Possible replacements include BPS, 2,4'-bis(hydroxyphenyl)sulfone (2,4-BPS), BPF, 2,2'-bis(4hydroxy-3-methylphenylphenyl)propane (BPC), and 4,4'-(1-Phenylethylidene)bisphenol (BPAP) among others (USEPA, 2014). However, it should be noted that the USEPA report outlines potential replacements with similar toxicity to that reported for BPA (such as for BPS, BPC and BPAP) or toxicity potentially higher than that reported for BPA such as in the 
case of BPF (USEPA, 2014). Bisphenol-S is now commonly used as a plasticizer; however, BPS has not been extensively evaluated in terms of its environmental presence and persistence in surface, ground, and drinking waters (Grignard et al., 2012). Recent evidence suggests BPS, BPF and BPAF are present at concentrations up to $19 \mathrm{ng} / \mathrm{L}, 3.4 \mathrm{ng} / \mathrm{L}$ and $246 \mathrm{ng} / \mathrm{L}$ respectively in Chinese rivers and that BPF and BPAF may more readily associate with sediment at concentrations of up to $30 \mathrm{ng} / \mathrm{g}$ and $2010 \mathrm{ng} / \mathrm{g}$ respectively (Yang et al., 2014). In the same study BPA was quantified up to $75 \mathrm{ng} / \mathrm{L}$ in river water and $43 \mathrm{ng} / \mathrm{g}$ in sediment (Yang et al., 2014). Plasticisers such as BPA and BPS have also been detected in street runoff during times of rainfall at levels up to 2410 and $50 \mathrm{ng} / \mathrm{L}$ respectively in greater London, UK (Wilkinson et al, 2016b). As replacements for plasticisers limited by regulatory bodies come to market, further and increasing research is needed to determine the environmental distribution as well as fate in sediment, suspended material and biota.

Table 3. Proportion of the parent compound excreted for 60 common pharmaceuticals (Upton et al., 1980; Baker et al., 1999; Jjemba, 2006)

\begin{tabular}{|c|c|c|c|c|}
\hline & Low: ( $\leq 5 \%)$ & $\begin{array}{c}\text { Moderately low: } \\
(6-39 \%)\end{array}$ & $\begin{array}{l}\text { Relatively high: } \\
(40-69 \%)\end{array}$ & High: ( $\geq 70 \%)$ \\
\hline Analgesics & $\begin{array}{l}\text { Aspirin, Ibuprofen, } \\
\text { Paracetamol, } \\
\text { Ketoprofen, } \\
\text { Neproxen }\end{array}$ & $\begin{array}{l}\text { Cromoglycate, } \\
\text { Diclofenac }\end{array}$ & Dexamethasone & Morphine \\
\hline Anesthetics & & Lidocaine & & \\
\hline Antimicrobials & $\begin{array}{l}\text { Acylovir, } \\
\text { Chloramphenicol }\end{array}$ & $\begin{array}{l}\text { Ampicillin, } \\
\text { Clindamycin, } \\
\text { Sulfamethoxazole }\end{array}$ & $\begin{array}{l}\text { Dicloxacillin, } \\
\text { Ethambutol, } \\
\text { Didanosine, } \\
\text { Fluconazole, } \\
\text { Metronidazole, } \\
\text { Minocycline, } \\
\text { Norfloxacin, } \\
\text { Trimethoprim, } \\
\text { Valaciclovir }\end{array}$ & $\begin{array}{l}\text { Amoxacillin, } \\
\text { Ciprofloxacin, } \\
\text { Doxycycline, } \\
\text { Cephalexin, } \\
\text { Flucytosine, } \\
\text { Genaconazole, } \\
\text { Tetracycline }\end{array}$ \\
\hline Antineoplastics & Idarubicin & Temozolomide & & \\
\hline Cardiovascular & $\begin{array}{l}\text { Atorvastatin } \\
\text { (Lipitor), Labetalol, } \\
\text { Quinapril, } \\
\text { Verapamil }\end{array}$ & $\begin{array}{l}\text { Enalapril (Vasotec), } \\
\text { Hydrochlorothiazide, } \\
\text { Procainamide, } \\
\text { Qiunidine, Ramipril, } \\
\text { Simvastatin (Zocor) }\end{array}$ & $\begin{array}{l}\text { Bezafibrate, } \\
\text { Clonidine, Digoxin, } \\
\text { Furosemide }\end{array}$ & \\
\hline Dopamirgics & & Nimodipine & & \\
\hline Gastrointestinal & & $\begin{array}{l}\text { Domperidone, } \\
\text { Rinitinide (Zantac) }\end{array}$ & & \\
\hline Reproductive & & & Testosterone & \\
\hline $\begin{array}{l}\text { Sedatives/ } \\
\text { antipsychotics }\end{array}$ & $\begin{array}{l}\text { Carbamazepine, } \\
\text { Valium, Fluoxentine } \\
\text { (Prozac), } \\
\text { Naltrexone }\end{array}$ & $\begin{array}{l}\text { Phenobarbitone, } \\
\text { Primidone }\end{array}$ & Atropine & Baclofen \\
\hline Uricosuric & Probenecid & & & \\
\hline
\end{tabular}




\subsection{Environmental Transport and Fate of PPCP and other Emerging Contaminants}

Traditionally, the contamination and fate of PPCPs and other emerging contaminants in river systems are studied through analysis of liquid samples. This is usually limited to monitoring parent compounds in the water (as opposed to rarer studies involving sediment, suspended solids and other mediums, e.g. biofilms, and other aquatic biota) of river ecosystems. Such an approach, while still informative in regard to contaminant attenuation within the water component of a river, does not represent the complete dynamics of PPCPS transport. Contaminant transport and fate in aquatic systems is still an evolving research area of PPCP environmental pollution, likely due to the relatively poorly understood and complex interactions between micro-organic contaminants and the environment within which they exist. The attenuation of contaminants in a river is very dynamic and dependent on specific factors relating to season, location, river hydrology, flow, biodegradation, association with other environmental compartments such as sediment and suspended particulate material, as well as river and contaminant-specific chemistry (Osenbruck et al., 2007; Musolff et al., 2009; Luo et al., 2011).

Point source contamination (e.g., sewage treatment facility effluent) is conceptually the simplest transport pathway to evaluate. After introduction into a river, contaminant concentrations are typically higher when effluent is discharged into tributaries with lower volume and slower flow rates than the main rivers, likely due to dilution effects (Silva et al., 2011). As contaminants flow down-stream, their interaction with the aquatic environment becomes more complex and less well understood. Ultimate fate and attenuation of contaminant concentrations can occur through several pathways/mechanisms, often depending on the properties of each individual compound, each individual river or aquatic system, biotic and abiotic contaminant degradation, how and when the compound was introduced to the environment, and its partition to solid components of the aquatic environment such as suspended solids and sediment (Osenbruck et al., 2007; Musolff et al., 2009). Much research is needed to further characterise the conditions leading to specific pathways of river transport and contaminant fate.

Table 4. Concentration ranges of 42 commonly detected pharmaceuticals, personal care products and other emerging contaminants in surface water (adapted from Wilkinson et al., 2016a)

\begin{tabular}{|l|lc|} 
Contaminant Class & Contaminant & $\begin{array}{c}\text { Surface water } \\
\text { (ng/L) }\end{array}$ \\
\hline Analgesic & Ibuprofen & $1-2370^{\mathrm{a}}$ \\
& Diclofenac & $<0.5-253^{\mathrm{a}, \mathrm{g}}$ \\
& Paracetamol & $110-10000^{\mathrm{b}, \mathrm{c}, \mathrm{g}}$ \\
& Codine & $12-1000^{\mathrm{b}, \mathrm{c}}$ \\
& Naproxen & $<1-81^{\mathrm{o}}$ \\
\hline Antibiotic & Amoxicillin & $<2.5-245^{\mathrm{a}}$ \\
& Erythromycin & $<0.5-159^{\mathrm{a}}$ \\
& Triclosan & $140-2300^{\mathrm{b}, \mathrm{c}}$ \\
& Trimethoprim & $<1-2^{\mathrm{p}}$ \\
& Sulfamethoxazole & $<1-46^{\mathrm{p}}$ \\
\hline Antidepressant & Amitriptyline & $66-207^{\mathrm{a}}$
\end{tabular}




\begin{tabular}{|c|c|c|}
\hline & $\begin{array}{l}\text { Fluoxetine } \\
\text { Venlafaxine }\end{array}$ & $\begin{array}{c}5.8-120^{\mathrm{a}, \mathrm{b}} \\
1.1-35^{\mathrm{a}}\end{array}$ \\
\hline \multirow[t]{3}{*}{ Antineoplastic } & Ifosfamide & $0.05-.14^{d}$ \\
\hline & Cyclophosphamide & $0.05-0.17^{d}$ \\
\hline & Tamoxifen & $<0.05-25^{n}$ \\
\hline \multirow[t]{2}{*}{ Alkylphenols } & 4-nonylphenol & $165.8-1187.6^{\mathrm{e}}$ \\
\hline & 4-t-octylphenol & $2.4-14.5^{\mathrm{e}}$ \\
\hline \multirow[t]{2}{*}{ Beta Blocker } & Metoprolol & $<0.5-10^{\mathrm{a}}$ \\
\hline & Atenolol & $<1-487^{\mathrm{a}}$ \\
\hline \multirow[t]{4}{*}{ Hormones/Steroids } & 17a-ethynylestradiol & $<0.98-10.2^{g}$ \\
\hline & $17 \beta$-estradiol & $0.1-200^{a, b}$ \\
\hline & 19-norethisterone & $48-872^{a, b}$ \\
\hline & Coprostanol & $<1-2717^{h}$ \\
\hline \multirow[t]{2}{*}{ Lipid regulator } & Bezafibrate & $<10-60^{\mathrm{a}}$ \\
\hline & Gemfibrozil & $48-790^{b, c}$ \\
\hline \multirow[t]{3}{*}{ Musk Compounds } & Linalool & $<0.5-0.6^{q}$ \\
\hline & Isobornyl acetate & $<0.18-0.65^{9}$ \\
\hline & Aroflorone & $<0.17-0.48^{\mathrm{q}}$ \\
\hline \multirow[t]{6}{*}{ Perfluoroalkyls } & 8:2 Fluorotelomer Alcohol & $<0.9-1.97^{m}$ \\
\hline & Perfluorobutane sulfonic acid* & $2.4-125^{f, g}$ \\
\hline & Perfluoro-2-propoxypropanoic acid* & $<1-630^{\prime}$ \\
\hline & Perfluorononanoic acid & $0.03-209^{f, g}$ \\
\hline & Perfluorooctanoic acid & $0.16-189^{f, g}$ \\
\hline & Perfluorooctane sulfonic acid & $0.4-2709^{f, g}$ \\
\hline \multirow[t]{5}{*}{ Plasticiser } & Bisphenol-A & $140-12000^{\mathrm{a}, \mathrm{b}, \mathrm{c}, \mathrm{g}}$ \\
\hline & Bisphenol-S** & $<1.02-306^{\mathrm{g}}$ \\
\hline & Bisphenol-AF** & $<1-246^{i}$ \\
\hline & Bisphenol-F** & $<1-1110^{j}$ \\
\hline & Diethyphthalate & $200-420^{b, c}$ \\
\hline \multirow[t]{2}{*}{ Ultraviolet Filters } & Benzophenone-4 & $<1-600^{k}$ \\
\hline & 2-Phenylbenzimidazole-5- sulfuric acid & $<1-20^{k}$ \\
\hline
\end{tabular}

*Compound used or proposed as a replacement for long-chain (>C7) perfluorinated compounds

** Compound used or proposed as a replacement for bisphenol-A

${ }^{\mathrm{a}}$ Petrie et al. (2015); ${ }^{\mathrm{b}}$ Kolpin et al. (2002); ${ }^{\mathrm{C}}$ Boyd et al. (2004); ${ }^{\mathrm{d}}$ Buerge et al. (2006);

${ }^{\mathrm{e}}$ Wang et al. (2012); ${ }^{\mathrm{f}}$ Llorca et al. (2012); ${ }^{\mathrm{g}}$ Wilkinson et al. (2017); ${ }^{\mathrm{h}} \mathrm{Peng}$ et al. (2008); ${ }^{\mathrm{i}}$ Yang et al. (2014); ${ }^{\mathrm{j}}$ Yamazaki et al. (2015); ${ }^{\mathrm{k}}$ Rodil et al. (2012); ${ }^{\mathrm{l}}$ Sun et al. (2016); ${ }^{\mathrm{m}}$ Mahmoud et al. (2009);

${ }^{\mathrm{n}}$ Coetsier et al. (2009); ${ }^{\circ} \mathrm{Li}$ (2014); ${ }^{\mathrm{p}}$ Van Stempvoort et al. (2013); ${ }^{\mathrm{q}} \mathrm{Relic}$ et al. (2017) 


\subsection{Atmospheric Transportation and Precipitation}

The atmosphere has been indicated as both a transport mechanism and source of several volatile PPCPs and other ECs (Hayes et al., 2002; 2003; Oono et al., 2008; Mahmoud et al., 2009). Fluorotelomer alcohols (FTOHs) are commonly reported emerging contaminants in the atmosphere and precipitation. FTOHs are widely produced with an estimated global production of 1.1-1.4 million kg/year and are commonly used as fluorotelomer-based acrylic polymers in water repellents for cloths, paper, packaging and carpet (Oono et al., 2008). The two most common FTOH compounds found in the atmosphere, 8:2 FTOH and 6:2 FTOH, were detected across 33 locations in Japan at concentrations of $32-247 \mathrm{pg} / \mathrm{m}^{3}$ and $<$ LOD$768 \mathrm{pg} / \mathrm{m}^{3}$ respectively (Oono et al., 2008). FTOH compounds have also been detected in Japanese precipitation and surface waters at concentrations ranging from 0.21-1.97 ng/L and 0.16-3.38 $\mathrm{ng} / \mathrm{L}$ respectively (Mahmoud et al., 2009).

Volatile emerging contaminants may enter the atmosphere via volatilisation from surface water or STWs as well as atmospheric emission during manufacture or incineration. Reviewing recent trends in the analysis and occurrence of PPCP/ECs in air, SalgueiroGonzález et al. (2015) suggest many common endocrine-disrupting compounds may associate with airborne particulate material (PM) less than $10 \mu \mathrm{m}$ in diameter. Furthermore, such contaminant-PM associates may be a potential source of such compounds to humans and other air-breathing organisms (Salgueiro-González et al. 2015). Levels of PM-bound contaminants are often significantly higher in indoor air than outdoor air, potentially due to poor ventilation and the widespread use of many such compounds in plastics and cleaning spray products (Rudel and Perovich, 2009; Salgueiro-González et al., 2015). Levels of commonly detected endocrine-disrupting phthalates, dibutyl phthalate (DBP), di(2ethylhexyl)phthalate (DEHP) and nonylphenol (NP) have been detected in outdoor air at levels of $55 \mathrm{ng} / \mathrm{m}^{3}$ (Salgueiro-González et al. 2013), $45 \mathrm{ng} / \mathrm{m}^{3}$ (Salapasidou et al., 2011) and $30.5 \mathrm{ng} / \mathrm{m}^{3}$ (Saito et al., 2004) respectively. In indoor air, DBP, DEHP and NP have been detected at significantly higher levels of as much as $2300 \mathrm{ng} / \mathrm{m}^{3}$ (Bergh et al., 2011), 1000 $\mathrm{ng} / \mathrm{m}^{3}$ (Rudel et al., 2003) and $680 \mathrm{ng} / \mathrm{m}^{3}$ (Saito et al., 2004) respectively. Further research is warranted to assess whether such airborne endocrine-disrupting compounds may influence inputs into the aquatic environment and indeed health implications on organisms exposed to such compounds, whether in air or water (Salgueiro-González et al. 2015).

Other contaminants, such as the herbicide atrazine, have been detected in precipitation geographically isolated from source areas, potentially entering the atmosphere via their application to land as sprays (Hayes et al., 2002; 2003). Rudel et al. (2003) detected endocrine-disrupting compounds including plasticisers, emulsifiers, nonylphenols, and an adhesive (4-tert-butylphenol) in the air of 52 of 89 homes tested at concentrations ranging from $50-1500 \mathrm{ng} / \mathrm{m}^{3}$. Furthermore, as discussed in section 2.1, agricultural spray drift of certain ECs used, for example in fruit tree production, can also transport such compounds atmospherically (Daughton, 2006). It is unclear how far such volatile compounds can travel in the atmosphere before entering the aquatic environment or being deposited on land through precipitation and more research is needed on this subject.

\subsection{River Flow and Adsorption to Sediment and Suspended Solids}

PPCPs and other ECs appear to attenuate in rivers at different rates largely depending on their sorption affinity to suspended solid/ sediment material (a higher affinity, indicating increased attenuation) and recalcitrance to biodegradation (a lower recalcitrance indicating 
increased attenuation) (Osenbruck et al., 2007). For example, carbamazepine, an antiepileptic, appears to attenuate in river water much slower than galaxolide, a musk compound commonly used in fragrances for soaps and detergents (Osenbruck et al., 2007). However, it is important to note that this attenuation does not necessarily indicate the compound has been removed. Adsorption to suspended solids in river water, sediments and banks can account for PPCP/EC contaminant attenuation, with some compounds preferentially binding to suspended solids rather than remaining dissolved (Luo et al., 2011; Silva et al., 2011). The antibiotic tetracycline, for example, appears to bind more preferentially to suspended solids and sediment than other antibiotic contaminants such as sulfonamides, quinolones and macrolides. Adsorption to suspended solid material is suggested to aid in the transportation of such compounds in the aquatic environment (Gregg et al., 2015). The physiochemical characteristics of contaminants as well as the properties of the adsorbing material itself are important in determining environmental fate (e.g., Luo et al., 2011; Wilkinson et al., 2017).

Luo et al. (2011) describe that cation exchange capacity and organic matter content of suspended solid material and sediment exert a great influence on contaminant adsorption (higher exchange capacity and organic matter indicating increased adsorption) and, in turn, attenuation. Similarly, Wilkinson et al. (2017) found that amphipathic compounds with long ( $\mathrm{C}>7)$ linear chains and polar moieties were more likely to adsorb to solid material found in the aquatic environment than those with short-chains or particularly non-polar molecules without ionisable functional groups (Wilkinson et al., 2017). High river flow rates are also suggested to decrease contaminant adsorption to solid material by limiting or preventing adequate contact time (Luo et al., 2011). Luo et al., (2011) found sulfonamides, quinolones and macrolide antibiotics were more significantly affected by increased river flow preventing their adsorption onto sediment and suspended solids than tetracycline (Luo et al., 2011). Compounds showing basic (pka>7) and hydrophobic characteristics appear to preferentially bind to suspended solids and sediment (Silva et al., 2011). At times, many preferentially-bound contaminants may not even be detected in the dissolved fraction of the aquatic environment, existing almost exclusively in suspended solids and sediments (Silva et al., 2011). Some common aquatic contaminants such as nonylphenol and nonylphenol monoethoxylate are found in suspended solid material and in sediment up to 21.5 and 4.7 times higher respectively than dissolved in river water (Patrolecco et al., 2006; Silva et al., 2011). Similarly, Gregg et al. (2015) demonstrate that polycyclic aromatic hydrocarbons bind to suspended particles in the Columbia River Estuary (northwest USA) at levels up to 10 times higher relative to those found dissolved in respective water. However, other common contaminants such as diazepam, erythromycin, gemfibrozil and metoprolol are found predominately, if not exclusively, dissolved in the aquatic environment rather than bound to solid fractions (Patrolecco et al., 2006; Silva et al., 2011).

It should be noted however that while levels of chemicals bound to suspended material are commonly reported in mass/mass units (e.g., ng/g dry weight), a more accurate comparison of their distribution may be reported as mass/volume of water the suspended material was separated from (e.g., $\mathrm{ng} / \mathrm{L}$ water the suspended material is separated from). Where levels of suspended particulate material in water are low, vast amounts of water may be needed to extract as little as $1 \mathrm{~g}$ of suspended material, making comparison to dissolved contaminant concentrations in a single litre of water potentially misleading. 
Research indicates that PPCP and other EC concentrations are generally lower in river sediment than suspended solids or in water (Silva et al., 2011). However, such findings remain relatively unclear, particularly regarding degradation product adsorption to suspended solids and sediments. Table 5 shows the measured concentration ranges of 14 pharmaceuticals in the surface water, suspended solids, and sediment of various rivers. Such data demonstrate that detection in the dissolved fraction of the aquatic environment alone is not an adequate measure of PPCP/EC occurrence

\subsection{Biodegradation of Organic Contaminants}

All PPCPs and other ECs will eventually degrade into other, less well-characterised compounds. Biological degradation transitions are generated by human and animal metabolism and by microorganisms present in sewage treatment works (STW), occurring naturally, in suspended solids, or sediments (Ferrando-Climent et al., 2012). Such transformations may occur via hydrolysis, oxidation, reduction and complete mineralization into inorganic carbon, oxygen, nitrogen or hydrogen mediated by microbes (Christensen and $\mathrm{Li}, 2014)$. High rates of biodegradation are typically observed in the sediment-water interface, wetlands and swamps with efficiency dependent on factors such as temperature, nutrient availability, $\mathrm{pH}$, river flow and salinity (Christensen and Li, 2014). Traditionally, research has focused on the presence of parent compounds in the aquatic environment rather than biodegradation transitions and much research is still needed to characterise PPCP/EC breakdown pathways and resulting molecules. Pharmaceuticals in particular are expected to breakdown along the metabolism of those taking them, resulting in an initial presence of degradation products in sewage treatment influent as contaminants themselves or glucuronide-transitions.

Microorganisms such as bacteria, fungi, microalgae and protozoa tend to degrade contaminants to a much greater degree (some to mineralization) than humans and animals, which often only transform organic compounds (e.g., via conjugation with glucuronides and sulfates) to a limited degree (Kumar et al., 2012; Christensen and Li, 2014). It is suggested that microbes may facilitate de-conjugation of excreted transformations. Kumar et al. (2012) show that glucuronide-conjugates of estrone and estradiol are completely transformed back to free parent estrogens during activated sludge treatment while sulfateconjugates are more resistant as only $10-55 \%$ were converted to parent estrogens. Similarly, in surface water, de-glucuronidation of estrone and estradiol yielded $60-100 \%$ parent estrogens at a half-life of 2 days (Kumar et al. 2012).

Enzymes are indicated to play an important role in the biodegradation of organic contaminants. Although precise degradation pathways are relatively unclear, overall enzyme-dependent degradation of PPCPs/ECs is suggested (Christensen and Li, 2014) to occur via a certain sequence of events: 1) transport of contaminant to microbe in a bioavailable manner (some hydrophobic contaminants may become unavailable for uptake by association with suspended solids), 2) contaminant uptake and diffusion through cell walls (to intracellular enzymes), 3) binding to enzyme reaction site and formation of contaminant-enzyme complex, 4) enzyme-contaminant reaction often mediated by cofactors and coenzymes and 5) release of the transformed product. It should be noted however that reaction sites are highly specific and attachment to and passage through biological membranes are largely dependent on the polarity and chemical composition of the specific contaminant. For example, hydrophobic PPCPs/ECs may more easily attach to 
the membrane and become more quickly degraded than hydrophilic compounds when the rate determining step is adsorption-dependent (Christensen and $\mathrm{Li}, 2014)$.

Contaminants are known to degrade during sewage treatment, particularly during activated sludge processing. Here microorganisms in biofilms degrade organic contaminants in a similar way as both fixed biofilms (more influential in small streams) and mobile aggregate biofilms (more influential in larger rivers) can degrade such organic compounds in the natural environment (Winkler et al., 2001). It should be noted however that there is a considerable lack of research into the role natural biofilms play in the environmental metabolism of organic contaminants. Within activated sludge treatment, Remberger et al. (2008) found the two main breakdown transitions of ibuprofen, hydroxyl- and carboxylibuprofen, at higher concentrations than the parent compound in sewage effluent. While ibuprofen is relatively well studied and good example of biodegradation, further research is needed to elucidate breakdown transitions and pathways of other common PPCPs and ECs. The toxicity of breakdown products, biodegraded or not, should also be considered as transformation products are indicated to be equally or more toxic (see section 6.4.3) as parent compounds (Ruggeri et al., 2013; Bergheim et al., 2014).

Table 5. Concentrations of 14 PPCP and other ECs in surface water, suspended solids, and sediment (Patrolecco et al., 2006; Silva et al., 2011)

\begin{tabular}{|l|l|l|l|}
\hline Compound & \multicolumn{1}{|c|}{ River Water (ng/L) } & \multicolumn{1}{|c|}{$\begin{array}{c}\text { Suspended Solids } \\
\text { (ng/g) }\end{array}$} & River Sediment (ng/g) \\
\hline Acetaminophen & n.d.-872 & n.d.-657 & n.d.-222 \\
\hline Atenolol & n.d-1237 & $3.06-34$ & n.d.-3.78 \\
\hline Diazepam & n.d-2.68 & n.d. & NA \\
\hline Diclofenac & n.d.-148 & n.d.-468 & $<$ LOQ-2.65 \\
\hline Erythromycin & n.d.-42.4 & NA & n.d.-33.5 \\
\hline Gemfibrozil & n.d.-160 & n.d.-47.1 & n.d.-5.2 \\
\hline Ibuprofen & n.d.-541 & n.d.-571 & n.d.-20.9 \\
\hline Metoprolol & n.d.-33.88 & n.d.-7.59 & n.d.-4.1 \\
\hline Naproxen & n.d.-109 & n.d.-38.5 & n.d.-1.87 \\
\hline Ranitidine & n.d.-84.5 & $19.4-133$ & n.d.-25.1 \\
\hline Bisphenol-A & $60-90$ & $<$ LOQ-610 & $<$ LOQ \\
\hline Nonylphenol & $150-340$ & $2680-7320$ & $380-970$ \\
\hline $\begin{array}{l}\text { Nonylphenol } \\
\text { monoethoxylate }\end{array}$ & $190-480$ & $1320-2260$ & $250-1780$ \\
\hline $\begin{array}{l}\text { Nonylphenol } \\
\text { diethoxylate }\end{array}$ & $70-400$ & $<$ LOQ-2430 & $50-320$ \\
\hline
\end{tabular}

LOQ - Limit of Quantification

n.d. - Not Detected

NA - Not Analysed

\subsection{Photochemical Transformation in the Aquatic Environment}

Photochemical transformation (or degradation) of organic contaminants in the aquatic environment occurs by both direct absorption of solar radiation and indirectly via reaction with photo-sensitized species. Via both direct and indirect mechanisms, energy from solar radiation results in the transformation of organic contaminants into other molecules by breaking covalent bonds typically resulting in more biodegradable and hydrolysable compounds (Richard and Canonica, 2005). Factors affecting the efficiency of photochemical 
transformation include the mechanism of degradation (direct or indirect), chemical nature of the compound being degraded, temperature, $\mathrm{pH}$, depth below the water surface, cloud coverage, altitude, latitude, and time of day (Remucal, 2014; Christensen and Li, 2014). While the degradation of specific contaminants via both direct and indirect photochemical transformation may be calculated or experimentally determined, generalising degradation potential across whole classes of compounds is difficult and often not reliable (Remucal, 2014). It should be noted however that photochemical transformation has been indicated as a means by which to degrade PPCP/ECs in STW effluent. Despite debate regarding the toxicity of some transformation products (Boreen et al., 2003; Latch et al., 2003b; Ruggeri et al., 2013; Bergheim et al., 2014), photocatalysis, photo-Fenton and UV with $\mathrm{H}_{2} \mathrm{O}_{2}$ have shown promising removal efficiencies and are reviewed in greater detail elsewhere as wastewater treatment strategies (e.g., Pereira et al., 2007; Ikehata et al., 2008; Wang and $\mathrm{Xu}, 2012)$.

\subsubsection{Direct Photochemical Transformation}

Direct photochemical transformation involves the non-reversible bond cleavage or rearrangement of organic molecules by the energy (photons) contained in sunlight reaching the Earth's surface, atmosphere, and shallow regions of the aquatic environment (Remucal, 2014). It should be noted that direct photochemical transformation of PPCPs/ECs in the aquatic environment is limited by the depth of water in which the compounds are found (Jasper and Sedlak, 2013). The majority of ultraviolent light, for example, is absorbed within the top $2 \mathrm{~m}$ of water (Dabrowska et al. 2004).

Sunlight reaching the earth's surface and shallow depths of the aquatic environment ranges in wavelength from about 290 to $600 \mathrm{~nm}$ (Dabrowska et al., 2004). Corresponding photo energy is of a similar order to many common covalent bonds found in organic contaminants (400 to $200 \mathrm{~kJ} / \mathrm{mol}$ ) such as $\mathrm{C}-\mathrm{C}, \mathrm{C}-\mathrm{H}, \mathrm{C}-\mathrm{O}, \mathrm{C}-\mathrm{Cl}$ and $\mathrm{C}-\mathrm{Br}$ (Christensen and $\mathrm{Li}$, 2014). The $\pi$-bond configuration of organic contaminants in the aquatic environment largely determines the absorptive capability (of sunlight) of the molecule via interaction with unbound electrons of heteroatoms such as nitrogen and oxygen (Christensen and Li, 2014). Most alcohols, acids, ethers and esters as well as most aliphatic hydrocarbons do not absorb light reaching the earth's surface (Christensen and Li, 2014). However, increased susceptibility to photochemical transformation is observed in molecules containing functional groups (e.g., $-\mathrm{CH}=\mathrm{CH} 2,-\mathrm{NO} 2,-\mathrm{NH} 2,-\mathrm{N}=\mathrm{N}$-, and $-\mathrm{OH}$ ) that are capable of donating additional $\pi$-electrons, thereby strengthening conjugated bonds (Christensen and Li, 2014). The absorption efficiency of light is assessed by the reaction quantum yield $(\Phi)$, calculated by the ratio of transformed moles to the total moles absorbing the light (Bezarez-Cruz et al., 2004). Reaction quantum yields $>1$ indicate chain reactions and most aquatic organic compounds show reaction quantum yields <0.01 (Christensen and $\mathrm{Li}, 2014$ ). Not all absorbed energy results in the transformation of absorbing molecules. Christensen and $\mathrm{Li}$ (2014) describe three alternative routes for absorbed photo energy: 1) energy may be released when excited molecules deactivate to ground state by either phosphorescence or fluorescence, 2) absorbed energy may be consumed by the respective molecule providing additional kinetic energy, and 3) energy may result in heat produced by collision with other molecules. Many organic contaminants are photodegraded by some combination of direct and indirect mechanisms. 


\subsubsection{Indirect Photochemical Transformation}

This pathway is mediated by chromophoric components in the aquatic environment which are photosensitized (or photo-induced/ excited) by solar radiation and then pass the excited energy on to organic compounds breaking chemical bonds and degrading the molecule (Richard and Canonica, 2005; Remucal, 2014). The occurrence of such reactions is dependent upon the amount of chromophores in the aquatic system and their ability to react (once sensitized) with respective organic contaminants. Such a pathway may be the dominant degradation process for aquatic contaminants that poorly absorb solar radiation directly (Richard and Canonica, 2005). Sensitizers absorb light (photons) becoming reactive photooxidant radicals such as $\mathrm{RO} \bullet, \mathrm{ROO} \bullet, \mathrm{HO} \bullet, \mathrm{HOO} \bullet,{ }^{1} \mathrm{O}_{2}, \mathrm{O}_{2}{ }^{-}$, and $\mathrm{CO}_{3}{ }^{-}$via reaction of bicarbonate and $\bullet \mathrm{OH}$ (Jasper and Sedlak, 2013; Christensen and Li, 2014; Remusal, 2014). Dissolved organic matter (DOM) can also act as a sensitizer (triplet DOM) in addition to inorganic species such as $\mathrm{NO}_{2}{ }^{-}$and $\mathrm{NO}_{3}{ }^{-}$(Dabrowska et al., 2004; Christensen and Li, 2014). Similar to energy lost in direct transformation, not all photosensitized species pass their excited energy on to break down organic contaminants. Photosensitized species may use their energy to deactivate others in a process called quenching making the resulting molecules less reactive (Christensen and Li, 2014). DOM may also decrease the efficiency of phototransformation by acting as an antioxidant and/or a sink for organic contaminants (Remucal, 2014).

\subsubsection{Photochemical Transformation of PPCPs/ECs in the Aquatic Environment}

The rate of PPCP/EC photochemical degradation is the sum of both direct and indirect transformations (Dabrowska et al., 2004). For example, in addition to thermal dissociation, phenol is degraded into oxalic acid and methanoic acid via both direct absorption of solar radiation and indirectly through oxidation by hydroxyl radicals in water (Wu et al., 2001; Dabrowska et al., 2004). However other PPCPs may undergo photochemical degradation more selectively, if at all. For example, cimetidine is photodegraded in water indirectly via reaction with singlet oxygen and is not susceptible to direct photochemical transformation (Latch et al., 2003a). Diclofenac has been shown to degrade into 1-(8-chlorocarbazolyl)acetic acid via photocyclization with further photochemical transformation via dechlorination resulting in carbazole products (Boreen et al., 2003). However, compounds with a high affinity for solids (such as tetracycline) may avoid photochemical degradation via sorption to suspended particulate materials (Boreen et al., 2003). As mechanisms of degradation and environmental distribution may differ between compounds and within groups of PPCPs/ECs, photoreactivity must be studied on a case-by-case basis (Boreen et al., 2003). It should be noted that study of photochemical degradation rates is often conducted in complete solvent or partial water-solvent systems and care must be taken in applying such findings to realworld conditions (Christensen and Li, 2014). For example, Packer et al. (2003) determined diclofenac readily degraded by direct photochemical transformation and the addition of isopropyl alcohol to the aqueous system resulted in a more rapid transformation, potentially due to formation of other radical species.

While much research has focused on determining photochemical degradation rates and quantum yields rather than elucidating mechanisms and transformation products, detailed review of photochemical transformations is available (e.g., Boreen et al., 2003; Wols and Hofman-Caris, 2012). Detailed research is needed in particular to determine 
toxicity of phototransformation products which can be equally, if not more biologically active than parent compounds (Boreen et al., 2003; Latch et al., 2003b; Ruggeri et al., 2013; Bergheim et al., 2014). Ibuprofen is shown to degrade via both direct and indirect photochemical transformation into 4-isobutylacetophenone (IBAP) which is known to adversely affect the central nervous system, red blood cells and connective tissue (Ruggeri et al., 2013). Here, transformation occurs via reaction with hydroxyl radicals $(2.3 \pm 0.1 \%$ yield), direct photolysis $(25 \pm 7 \%$ yield) and reaction with excited DOM ( $31 \pm 4 \%$ yield) producing IBAP concentrations up to approximately $15 \%$ of ibuprofen levels in respective water (Ruggeri et al., 2013). Similarly, Latch et al. (2003b) determine that triclosan degrades via exposure to UV light into the potentially toxic 2,8-dichlorodibenzo-p-dioxin in aqueous medium with condition-specific yields of $1-12 \%$. Noting the difficulty of product identification, Boreen et al. (2003) suggest coupling biological assays with photochemical studies. Here, potential biological effects of photochemical transformation products may be assessed without identifying the products themselves by comparing changes in biological endpoints before and after transformation of the parent compound. Using such methodology, Bergheim et al. (2014) tested the direct photodegradability and toxicity of 14 pharmaceuticals found in the aquatic environment (acyclovir, allopurinol, cetirizine, cimetidine, fluconazole, hydrochlorothiazide, lisinopril, phenytoin, primidone, ranitidine, sotalol, sulpiride, tramadol and valsartane). Of the selected pharmaceuticals, acyclovir, allopurinol and fluconazole resisted direct photochemical transformation via exposure to UV light (Bergheim et al., 2014). Furthermore, irradiated solutions of $8 \mathrm{mg} / \mathrm{L}$ cetirizine, cimetidine, tramadol and valsartane demonstrated higher toxicity in growth inhibition assays to bacteria $P$. putida than non-irradiated solutions. Similarly, irradiated solutions of hydrochlorothiazide, ranitidine, sulpiride tramadol and valsartane showed greater inhibition of $V$. fischeri bioluminescence than non-irradiated solutions (Bergheim et al., 2014).

Identification of photochemical transformation products as well as assessment of their potential ecological impacts and environmental occurrence remain relatively understudied topics (Bergheim et al., 2014). Future research should proceed with focus on the environmental occurrence and toxicology of photochemical transformation products identified by primary laboratory work.

\subsection{PPCPs and other ECs in Sewage Biosolids used as Agricultural Additives}

Biosolids are an end product of sewage treatment and are used as agricultural conditioners and fertilisers. Agricultural use of such municipal biosolids has increased in the EU since a commission prohibition on their disposal at sea in 1998 (Barron et al., 2010). The U.S. Environmental Protection Agency (USEPA) estimates about $50 \%$ of biosolids produced in the USA are used for agricultural purposes on less than $1 \%$ of the nation's farmland (USEPA, 2012). Throughout treatment, sewage sludge retains many contaminants, including a complex mixture of PPCPs and other emerging contaminants. The use of such biosolids on agricultural lands inevitably introduces organic contaminants including PPCPs which may ultimately result in soil contamination, groundwater recharge to aquifers, runoff, and possible uptake by agricultural plants (Daughton, 2006; Barron et al., 2010). Introduction of emerging organic contaminants to soil in this manner has raised concern over recent years. Current regulation on the quality of biosolids used for agricultural purposes does not take contamination by PPCP and other ECs into account (USEPA, 2012). 
The fate and persistence of biosolid-borne PPCP contaminants in soils appear to be compound-, site/soil-, and climate-specific. While hydrophobicity and soil organic carbon content do affect contaminant adsorption, they are alone not sufficient variables in estimating PPCPs behaviour in soils (Barron et al., 2010). Variables more significantly affecting contaminant adsorption in soils (via the application of biosolids to topsoils) may include the degree of soil water-saturation, rate of percolation, physicochemical properties of both the solid matrix and compounds, temperature of the soil, and $\mathrm{pH}$ of the soil/liquid solution (Barron et al., 2010).

Reviewing the use of biosolids in agricultural soil, Clarke and Smith (2011) conclude that despite over 143,000 chemicals being registered for industrial use in the European Union (all of which could potentially be found in biosolids), the risk of contaminant uptake into agricultural plants causing implications on human health is not significant. PPCPs and other ECs are detected in sewage biosolids at concentrations typically not exceeding 10 $\mathrm{mg} / \mathrm{kg}$ dry weight (dw), although exceptions do exist (Clarke and Smith, 2011). For example, pharmaceuticals ciprofloxacin and ofloxacin have been detected up to 40.8 and $58.1 \mathrm{mg} / \mathrm{kg}$ dw sludge respectively in the USA (US EPA, 2009) while plasticisers bisphenol-A (BPA) and bis(2-ethylhexyl) phthalate (DEHP) have been detected up to $325 \mathrm{mg} / \mathrm{kg} \mathrm{dw}$ (Meesters and Schroder, 2002) and $3514 \mathrm{mg} / \mathrm{kg}$ dw (Abad et al., 2005) in Germany and Spain respectively.

Further research is warranted particularly regarding such contaminants leaching into the aquatic environment, including into aquifers. Additionally, with increased demand to recover phosphorus from wastewater treatment facilities, including from sludge (Melia et al., 2017), study should be undertaken to evaluate the effect of phosphorous recovery on concentrations of PPCPs/ECs in biosolids and in phosphorus recovery products.

\subsection{Temporal and Seasonal Effects on PPCP and ECs in water}

Many of the factors affecting contaminant attenuation can fluctuate with seasonal and meteorological changes (Vieno et al., 2005; Musolff et al., 2009). Most notable fluctuations seemed to be linked to temperature changes in receiving waters, volumes of receiving waters, and changes in seasonal PPCP/EC use (e.g., sunscreens, personal insecticides and caffeine). During warmer months, increased water temperature has been associated with increased attenuation of contaminants in surface waters, potentially due to increased microbial and biofilm activity (Musolff et al., 2009). Changes in river volume can also affect the concentration of contaminants, mainly by dilution. For example, Vajda et al. (2008) describe how the increased stream volume of Boulder Creek (Colorado, USA) during warmer months, due to snowmelt from the Rocky Mountains, reduces the dominance of STW effluent in river volume (and hence PPCP and EC discharge) by as much as $>75 \%$.

Last, temporal and seasonal changes in compound use occur and can directly affect concentrations of PPCPs/ECs in the aquatic environment. In the city of Leipzig (Germany), periods of rainfall and colder months saw increased loading of both caffeine and 4nonylphenol indicating weather and season as factors in contaminant loading (Musolff et al., 2009). It is unclear how seasonal changes in population can affect environmental loading of PPCP and other emerging contaminants. Such population fluctuations could be a factor in cities with seasonal tourism or high student populations (e.g., university towns). However, research is lacking in terms of the exact affect population fluctuation has on contaminant loading. 


\subsection{Micro- and nanoplastic particles in the aquatic environment}

Evidence exists suggesting that certain PPCP and other EC contaminants may bind to plastics particles in the aquatic environment (Mato et al., 2001; Rios et al., 2007; Teuten et al., 2009; Hirai et al., 2011; Wegner et al., 2012; Rochman, 2016). Microplastics are defined by a diameter of $1 \mu \mathrm{m}-5 \mathrm{~mm}$ while nanoplastics a diameter of $<1 \mu \mathrm{m}$ (Browne et al., 2008). However, it should be noted that the very definition of nanoplastics is debated as the European Commission defines nanoplastics with a particle diameter between $1 \mathrm{~nm}-100 \mathrm{~nm}$ (Europe Commission, 2015).

Plastic particles, which are ubiquitous in the aquatic environment, do not biodegrade, but do however do degrade (National Oceanic and Atmospheric Administration, 2016). In addition to being used in cosmetic products (i.e., facial scrubs and toothpaste), microplastic particles are formed via the degradation of larger (manufactured state) plastic objects over hundreds of years and may never be completely eliminated from the environment (National Oceanic and Atmospheric Administration, 2016). Both primary production and fragmentation (e.g., via ultraviolet light exposure) of larger plastic particles into micro-and nanoparticles are thought to be major contributors to the substantial amounts present in the aquatic environment (Eriksen et al., 2014). Fragmentation of microplastics into nanoplastics increases surface area to volume ratio which in turn may affect the area of plastic available for organic contaminants to bind (European Union Commission, 2011). Woodall et al. (2014) report abundance of microplastics in ocean sediment up to 4 orders of magnitude higher than that detected in sea-surface water indicating that sediment may be a significant sink for these contaminants. In the same study, plastic microparticles were identified in all sediment samples at abundances ranging from 1.4-40 pieces $/ 50 \mathrm{~mL}$ sediment and consisted predominately of rayon and polyester (Woodall et al., 2014).

Some organic contaminants have been shown to bind to plastic particles in the aquatic environment at similar concentrations to suspended solids and sediments (Mato et al., 2001; European Union Commission, 2011; Rochman, 2016). Among the first to demonstrate this, Mato et al. (2001) recovered PCBs, DDE, and nonylphenols bound to plastic particles at concentrations of $4-117 \mathrm{ng} / \mathrm{g}$ plastic, $0.16-3.10 \mathrm{ng} / \mathrm{g}$, and $0.13-16 \mathrm{ng} / \mathrm{g}$ respectively. More recently, Hirai et al. (2011) found hydrophobic contaminants more likely to accumulate on plastics. In the same study, common ECs were detected on plastic particles at up to $730 \mathrm{ng}$ BPA/g plastic and nonylphenol up to $3936 \mathrm{ng} / \mathrm{g}$ (Hirai et al., 2011). However, it is important to note that plasticisers such as BPA and nonylphenol have been shown to leach from plastic material such as polyethylene, silicone (nonylphenol only), polycarbonate and polystyrene (Fasano et al., 2012). Hence, levels of these chemicals found on plastic particles in the environment may only represent desorption from the plastic itself during extraction in the laboratory rather than adsorption of the chemicals to the plastic from the environment, or a combination of both. Study investigating the accumulation of ECs and PPCPs onto micro- and nanoplastics in the environment is limited but is rapidly increasing in recent years. Research is likely most significantly limited by the difficulties in retrieving such particles from environmental matrices.

Aquatic organisms may ingest plastic particles, perhaps mistaking them for eggs, bringing to light a possible route of exposure when PPCPs/ECs are bound to the particles (Mato et al., 2001; Wegner et al., 2012). Boerger et al. (2010) found ingested plastic particles in $35 \%$ of plankton-eating fish caught in the North Pacific Gyre. Similar findings 
were reported in Brazilian estuaries where 18-33\% of collected catfish were found with plastic particles in their stomachs (Possatto et al., 2011). Ingestion of contaminated particles may influence biological disruption in exposed organisms (European Union Commission, 2011) and may result in the bioaccumulation of adsorbed chemicals in animals that consume the particles (Rochman, 2016). The degree to which levels of contaminants attached to plastic particles may affect the biology of the organisms, consuming them is not well-known and may be specific to the species and period of development an individual is exposed (Rochman, 2016).

The presence of plastic micro- and nanoparticles in the environment is likely to remain a key issue in the field longer than many others due to the amounts of the material in the aquatic environment and its inability to fully degrade (National Oceanic and Atmospheric Administration, 2016). In recent years, regulatory and government bodies have begun banning the use of microplastic particles in cosmetic products (Table 6).

Table 6. Summary of significant regulation set on the sale, manufacture and import of products containing plastic microparticles across the world as of early 2017

\begin{tabular}{|c|c|c|c|}
\hline Country & $\begin{array}{l}\text { Implementation } \\
\text { Date }\end{array}$ & Regulation & Comments \\
\hline Canada & 1 July, 2018 & $\begin{array}{l}\text { Changes to the } \\
\text { Canadian } \\
\text { Environmental } \\
\text { Protection Act }\end{array}$ & $\begin{array}{l}\text { Ban on the sale of shower gels, facial scrubs and } \\
\text { toothpaste containing plastic microbeads from } 1 \text { July } \\
2018 \text {. Manufacture banned six months before the } \\
\text { sales ban. Additional ban on natural products and } \\
\text { non-prescription drugs containing microplastics from } \\
1 \text { July, } 2019 \text {. }\end{array}$ \\
\hline France & $\begin{array}{l}\text { Proposed: } 1 \\
\text { January, } 2018\end{array}$ & $\begin{array}{l}\text { Proposed at the } \\
\text { time of writing }\end{array}$ & $\begin{array}{l}\text { Prohibit the sale of cosmetic products containing } \\
\text { microplastic particles and cotton buds with plastic } \\
\text { stems in France. }\end{array}$ \\
\hline $\begin{array}{l}\text { New } \\
\text { Zealand }\end{array}$ & 1 July, 2018 & $\begin{array}{l}\text { Changes to the } \\
\text { Waste Minimisation } \\
\text { Act of } 2008\end{array}$ & $\begin{array}{l}\text { Ban on the manufacture and sale of personal care } \\
\text { products containing plastic microbeads. Penalty of } \\
\$ 73,000 \text { (USD) for any entity found in breach of the } \\
\text { ban (Waste Minimisation Act of 2008). }\end{array}$ \\
\hline $\begin{array}{l}\text { South } \\
\text { Korea }\end{array}$ & $\begin{array}{l}\text { Proposed: July } \\
2017 \\
\text { (manufacture and } \\
\text { import), July } 2018 \\
\text { (cosmetic product } \\
\text { sale) }\end{array}$ & $\begin{array}{l}\text { Proposed at the } \\
\text { time of writing }\end{array}$ & $\begin{array}{l}\text { Ban on the manufacture and import of cosmetic } \\
\text { products containing plastic particles from July } 2017 \\
\text { and ban their sale from July } 2018 \text {. }\end{array}$ \\
\hline Taiwan & Proposed: 2017 & $\begin{array}{l}\text { Proposed at the } \\
\text { time of writing by } \\
\text { Taiwan's } \\
\text { Environmental } \\
\text { Protection Agency }\end{array}$ & $\begin{array}{l}\text { Prohibits the sale, import and manufacture of } \\
\text { personal care products and toothpastes containing } \\
\text { plastic particles. }\end{array}$ \\
\hline $\begin{array}{l}\text { United } \\
\text { Kingdom }\end{array}$ & $\begin{array}{l}\text { Proposed: } \\
\text { October } 2017\end{array}$ & $\begin{array}{l}\text { Proposed at the } \\
\text { time of writing }\end{array}$ & $\begin{array}{l}\text { Prohibits the manufacture and sale of cosmetic } \\
\text { products and personal care products which contain } \\
\text { microplastic particles which may cause harm to the } \\
\text { marine environment (DEFRA, 2017) }\end{array}$ \\
\hline $\begin{array}{l}\text { United } \\
\text { States }\end{array}$ & $\begin{array}{l}\text { July } 2017 \\
\text { (manufacture), } \\
\text { January } 2018 \\
\text { (cosmetic product } \\
\text { sale) }\end{array}$ & $\begin{array}{l}\text { Microbead-Free } \\
\text { Waters Act of } 2015\end{array}$ & $\begin{array}{l}\text { Prohibits the manufacture and interstate commerce } \\
\text { of cosmetic products with intentionally-added wash- } \\
\text { off plastic particles }>5 \mathrm{~mm} \text { in diameter. Manufacture } \\
\text { of microbeads banned from July } 2017 \text { and ban of the } \\
\text { sale of cosmetic products containing microbeads from } \\
\text { January } 2018 \text { (Microbead-Free Waters Act of 2015). }\end{array}$ \\
\hline
\end{tabular}




\subsubsection{Significant legislation regulating the manufacture, sale and import of products containing plastic particles}

At the time of writing (early 2017), only the United States, Canada and New Zealand had legislated clear regulation of the manufacture, sale and import of cosmetic products containing plastic particles $>5 \mathrm{~mm}$ in diameter (Table 6). Other nations including the United Kingdom, Taiwan, South Korea and France have proposed legislation (at the time of writing) which would take effect between late 2017 to mid 2018. Although individual U.S. states including California, Colorado and New York had previously implemented bans on the sale of cosmetic products containing plastic particles, the United States-wide congressional legislation H.R. 1321 (Microbead-free Water Act of 2015) was the first major regulatory decision on plastic microparticles. Much of the following regulation by other nations followed the template of H.R. 1321, which included an initial ban on the manufacture of plastic micropartles followed by a subsequent ban ( 6 months later) on the sale and import of cosmetic products containing plastic microparticles (Table 6). At the time of writing, no European Union-wide legislation is proposed despite the governments of Austria, Belgium, Sweden, Luxembourg and the Netherlands calling for an EU-wide ban in 2014 (Council of the European Union, 2014).

Despite regulatory decisions, as microplastics are also produced by degradation of larger plastic pieces (National Oceanic and Atmospheric Administration, 2016), such legislation is likely to not have a significant effect on the amount of microplastic particles in the environment for many hundreds of years. Research should focus on determining their possible environmental implications rather than mechanisms to reduce their prevalence.

\subsection{Conclusions and Direction for Research}

Contamination of water by pharmaceutical, personal care products and other emerging contaminants is unavoidable as long as their uses remain such an indispensable component of a modern and healthy society. Such contaminants are virtually ubiquitous in the aquatic environment and are rarely detected in some drinking waters (Jjemba, 2006; Silva et al., 2011; Raghav et al., 2013; United States Geological Survey, 2016a). Currently, technology and techniques utilised in sewage/wastewater, and potentially drinking water, treatment are not complete barriers to these contaminants. While future research must focus on increasing PPCP/EC removal efficiencies in sewage treatment, complete removal prior to environmental introduction is likely not practical (Radjenovic et al., 2009; Hirani et al., 2013).

Future study may focus on the elucidation of largely unknown breakdown products and their formation during sewage treatment, natural photochemical transformation and biological degradation. The potential environmental toxicity of such breakdown products should also be considered as some transformation products may be equally, if not more toxic than parent compounds (Boreen et al., 2003; Latch et al., 2003b; Ruggeri et al., 2013; Bergheim et al., 2014). Such investigation could be undertaken as suggested by Boreen et al. (2003) where biological assays are coupled with degradation study in such a way that adverse biological outcomes are assessed and compared before and after transformation of parent compounds without having to identify the breakdown products themselves. Subsequently, more detailed study could identify the specific chemical structures of 
transformation products produced under study conditions which may mimic those observed in specific sewage treatment facilities. Such STW-specific conditions, when coupled with quantitative structural-activity relationship models and the abovementioned toxicity assessments may inform the creation of novel models for predicting the toxicity of transformation products under defined conditions.

Much remains to be elucidated regarding variables and conditions influencing the environmental fate and attenuation of PPCPs and other ECs. Some contaminants appear to bioaccumulate, preferentially bind to suspended solids or river sediment, volatilise, interact with other environmentally present components (plastics, heavy metals), and breakdown into unknown or poorly understood metabolites, each with potentially independent fates and behaviours. This concept particularly challenges the identification of contaminants present in the environment as some may only exclusively present in certain aquatic matrices leading to great uncertainty regarding where exactly to look (Patrolecco et al., 2006; Silva et al., 2011). Much research and classification is still needed to understand the environmental fate and metabolism of PPCP and other ECs, particularly when associating with media such as biofilms, micro-/nanoplastic particles and distribution between dissolved and lessbioavailable bound fractions in water. Specific work focusing on the factors influencing the uptake of ionisable chemicals into aquatic organisms is warranted.

Four overarching challenges are posed at present which present the need for continued and future, likely highly-interdisciplinary research:

1) Identification of new environmentally present contaminants and both new and existing transformation products is particularly challenging as new drugs and replacements for regulatory limited compounds are continually being introduced to market and subsequently into the environment;

2) Compounds used to replace those which are statutory/regulation-limited must be comprehensively studied to elucidate ultimate environmental fate and potential toxicity. Such research may focus on perfluorinated compounds of $<6$ carbon chains such as PFBS as well as plasticisers BPS, BPF and BPAF;

3) The presence of antibiotics in the aquatic environment is thought to have a role in the development of antimicrobial resistance (see section 2.2). Study may most efficiently focus on the potential transfer mechanisms of antibiotic-resistant genes originating from bacteria within sewage treatment facilities and urban wastewater systems to bacteria in receiving surface waters and potential risk reduction using disinfection (e.g., UV) at STW facilities; and

4) As regulation will likely not eliminate the presence of plastic particles in the environment for many thousands of years (as plastic does not degrade but simply fragments), specific research is warranted to determine the effects/rate of plastic fragmentation on potential particle toxicity (if any), ability to retain emerging contaminants (if any), uptake by organisms and distribution in the environment.

Since the late 1990s, significant progress has been made in the understanding of the sources, occurrence and fate of pharmaceuticals, personal care products and other 
emerging contaminants. Regardless, this topic is likely to dominate emerging environmental chemistry for many years to come as our understanding of the field becomes deeper and ultimately more interdisciplinary.

\subsection{References}

Abad E., Martinez, K., Planas C., Palacios O., Ciaxach, J. and Rivera, J., 2005, "Priority organic pollutant assessment of sludges for agricultural purposes," Chemosphere, vol., 61, no. 9, pp. 1358-1369.

Al Aukidy, M., Verlicchi, P., Jelic, A., Petrovic, M., \& Barcelò, D., 2012, “Monitoring release of pharmaceutical compounds: occurrence and environmental risk assessment of two WWTP effluents and their receiving bodies in the Po Valley, Italy", Science of the Total Environment, vol. 438, pp. 15-25.

American Dental Association 2016, "Oral Health Topics: ADA Statement on Bisphenol A and Dental Materials," [online], available at <http://www.ada.org/en/member-center/oral-healthtopics/bisphenol-a> [Last accessed 18 April 2016]

Arvaniti, O.S. and Stasinakis, A.S., 2015. Review on the occurrence, fate and removal of perfluorinated compounds during wastewater treatment. Science of the Total Environment, 524, pp.81-92.

Baker, S.D., Wirth, M., Statkevich, P., Reidenberg, P., Alton, K., Sartorius, S.E., Dugan, M., Cutler, D., Batra, V., Grochow, L.B., Donehower, R.C. \& Rowinsky, E.K., 1999, "Absorption, metabolism, and excretion of 14C-temozolomide following oral administration to patients with advanced cancer", Clinical cancer research: an official journal of the American Association for Cancer Research, vol. 5, no. 2, pp. 309-317.

Baquero, F., Martínez, J. \& Cantón, R., 2008, "Antibiotics and antibiotic resistance in water environments", Current Opinion in Biotechnology, vol. 19, no. 3, pp. 260-265.

Barnes, K.K., Kolpin, D.W., Meyer, M.T., Thurman, E.M., Furlong, E.T., Zaugg, S.D. \& Barber, L.B., 2002, Water-quality data for pharmaceuticals, hormones, and other organic wastewater contaminants in US streams, 1999-2000, US Department of the Interior, US Geological Survey.

Barron, L., Nesterenko, E., Hart, K., Power, E., Quinn, B., Kelleher, B. \& Paull, B., 2010, "Holistic visualisation of the multimodal transport and fate of twelve pharmaceuticals in biosolid enriched topsoils", Analytical and Bioanalytical Chemistry, vol. 397, no. 1, pp. 287-296.

Barraza, L., 2013, "A new approach for regulating bisphenol A for the protection of the public's health," The Journal of Law, Medicine \& Ethics, vol. 41, no. s1, pp. 9-12.

Baumann, L., Knorr, S., Keiter, S., Rehberger, K., Volz, S., Schiller, V., and Braunbeck, T. (2014). Revers- ibility of endocrine disruption in zebrafish (Danio rerio) after discontinued exposure to the estrogen 17a-ethinylestradiol. Toxicology and Applied Pharmacology, 278(3), 230237.

Benotti, M.J. \& Brownawell, B.J., 2009, "Microbial degradation of pharmaceuticals in estuarine and coastal seawater", Environmental Pollution, vol. 157, no. 3, pp. 994-1002.

Bergh, C., Torgrip, R., Emenius, G., \& Ostman, C., 2011, "Organophosphate and phthalate esters in air and settled dust - a multi-location indoor study", Indoor Air, vol. 21, pp. 67-76.

Bergheim, M., Gminski, R., Spangenberg, B., Dębiak, M., Bürkle, A., Mersch-Sundermann, V., Kümmerer, K. and Gieré, R., 2014, "Recalcitrant pharmaceuticals in the aquatic environment: a comparative screening study of their occurrence, formation of phototransformation products and their in vitro toxicity," Environmental Chemistry, vol. 11, no. 4, pp.431-444.

Berglund, B., 2014, "Deliberations on the impact of antibiotic contamination on dissemination of antibiotic resistance genes in aquatic environments", (Doctoral dissertation), retrieved from Digitala Vetenskapliga Arkivet. Linköping, Sweden: Linköping University Electronic Press. ISBN: 978-91-7519-361-8, DOI: 10.3384/diss.diva-105872.

Besse, J.P., Latour, J.F., \& Garric, J., 2012, "Anticancer drugs in surface waters: what can we say about the occurrence and environmental significance of cytotoxic, cytostatic and endocrine therapy drugs?", Environment International, vol., 39, no. 1, pp. 73-86. 
Bezares-Cruz, J., Jafvert, C.T., Hua, I., 2004. Solar photodecomposition of decabromodiphenyl ether: products and quantum yield. Environ. Sci. Technol. 38, 4149-4156.

Boerger, C.M., Lattin, G.L., Moore, S.L. \& Moore, C.J., 2010, "Plastic ingestion by planktivorous fishes in the North Pacific Central Gyre", Marine Pollution Bulletin, vol. 60, pp. 2275-2278.

Boreen, A.L., Arnold, W.A. and McNeill, K., 2003, "Photodegradation of pharmaceuticals in the aquatic environment: a review," Aquatic Sciences, vol. 65, no. 4, pp. 320-341.

Boyd, G.R., Palmeri, J.M., Zhang, S. \& Grimm, D.A., 2004, "Pharmaceuticals and personal care products (PPCPs) and endocrine disrupting chemicals (EDCs) in stormwater canals and Bayou St. John in New Orleans, Louisiana, USA", Science of the Total Environment, vol. 333, no. 1, pp. 137148.

Brausch, J.M. and Rand, G.M., 2011, "A review of personal care products in the aquatic environment: Environmental concentrations and toxicity," Chemosphere, vol. 82, no. 11, pp. 1518-1532.

Browne, M.A., Dissanayake, A., Galloway, T.S., Lowe, D.M., \& Thompson, R.C., 2008, "Ingested microscopic plastic translocates to the circulatory system of the mussel, Mytilus edulis (L.)", Environmental Science \& Technology, vol. 42, no. 13, pp. 5026-5031.

Buerge I.J., Buser H.-R., Poiger T., \& Müller M.D., 2006, "Occurrence and fate of the cytostatic drugs cyclophosphamide and ifosfamide in wastewater and surface waters", Environmental Science \& Technology, vol. 40, no. 23, pp. 7242-50.

Brezovšek, P., Eleršek, T. \& Filipič, M., 2014, "Toxicities of four anti-neoplastic drugs and their binary mixtures tested on the green alga Pseudokirchneriella subcapitata and the cyanobacterium Synechococcus leopoliensis", Water Research, vol. 52, pp. 168-177.

Browne, M.A., Dissanayake, A., Galloway, T.S., Lowe, D.M., \& Thompson, R.C., 2008, "Ingested microscopic plastic translocates to the circulatory system of the mussel, Mytilus edulis (L.)" Environmental Science \& Technology, vol. 42, no. 13, pp. 5026-5031.

Caliman, F.A. \& Gavrilescu, M., 2009, "Pharmaceuticals, personal care products and endocrine disrupting agents in the environment-a review", CLEAN-Soil, Air, Water, vol. 37, no. 4-5, pp. 277303.

Centers for Disease Control, 2010, Sept-last update, Prescription drug use continues to increase: U.S. prescription drug data for 2007-2008 [Homepage of Centers for Disease Control], [Online]. Available: <http://www.cdc.gov/nchs/data/databriefs/db42.pdf> [2014, 18 June].

Chokwe, T.B., Okonkwo, J.O., Sibali, L.L. and Ncube, E.J., 2015, "Alkylphenol ethoxylates and brominated flame retardants in water, fish (carp) and sediment samples from the Vaal River, South Africa," Environmental Science and Pollution Research, vol. 22, no. 15, pp.11922-11929.

Christensen, E.R. and Li, A., 2014, "Physical and Chemical Processes in the Aquatic Environment," Wiley \& Sons, Inc.: Hoboken, pp 255-259.

Clarke, B.O. and Smith, S.R., 2011, "Review of 'emerging' organic contaminants in biosolids and assessment of international research priorities for the agricultural use of biosolids," Environment International, vol. 37, no. 1, pp. 226-247.

Coetsier C.M., Spinelli S., Lin L., Roig B., Touraud E., 2009, "Discharge of pharmaceutical products (PPs) through a conventional biological sewage treatment plant: MECs vs PECs?", Environment International, vol. 35, no. 5, pp. 787-92.

Colin, A., Bach, C., Rosin, C., Munoz, J.F. and Dauchy, X., 2014. Is drinking water a major route of human exposure to alkylphenol and bisphenol contaminants in France? Archives of Environmental Contamination and Toxicology, vol. 66, no. 1, pp.86-99.

Corrales, J., Kristofco, L. A., Steele, W. B., Yates, B. S., Breed, C. S., Williams, E. S., \& Brooks, B. W., 2015. Global Assessment of Bisphenol $A$ in the Environment Review and Analysis of Its Occurrence and Bioaccumulation. Dose-Response, vol. 13, no. 3, pp. 1-29.

Council of the European Union, 2014. Elimination of micro-plastics in products - an urgent need Information from the Belgian, Dutch, Austrian and Swedish delegations, supported by the 
Luxembourg delegation, [pdf] (last accessed 31 August 2017), available at: <http://register.consilium.europa.eu/doc/srv?l=EN\&f=ST\%2016263\%202014\%20INIT>.

Dabrowska, D., Kot-Wasik, A. and Namiesnik, J., 2004, "The importance of degradation in the fate of selected organic compounds in the environment. Part II. Photodegradation and biodegradation," Polish Journal of Environmental Studies, vol. 13, no. 6, pp. 617-626.

Daughton, C.G., 2006, Origins and fate of PPCPs in the environment, United States Environmental Protection Agency, Las Vegas.

DEFRA, 2017. Microbead ban announced to protect sealife. [online] (last accessed 31 August 2017), available at: <https://www.gov.uk/government/news/microbead-ban-announced-to-protectsealife>.

Eriksen, M., Lebreton, L.C., Carson, H.S., Thiel, M., Moore, C. J., Borerro, J.C., Galgani, F., Ryan, P.G., and Reisser, J., 2014, "Plastic pollution in the world's oceans: more than 5 trillion plastic pieces weighing over 250,000 tons afloat at sea", PLOS ONE, vol. 9, no. 12, e111913.

European Commission, 2015, "Definition of a nanomaterial," [European Commission, Environment], [online], Available at $:<$ http://ec.europa.eu/environment/chemicals/nanotech/faq/definition_en.htm> [Last accessed 8 Nov 2015].

Farré, M.I., Pérez, S., Kantiani, L. \& Barceló, D., 2008, "Fate and toxicity of emerging pollutants, their metabolites and transformation products in the aquatic environment", TrAC Trends in Analytical Chemistry, vol. 27, no. 11, pp. 991-1007.

Fasano, E., Bono-Blay, F., Cirillo, T., Montuori, P. and Lacorte, S., 2012, "Migration of phthalates, alkylphenols, bisphenol A and di (2-ethylhexyl) adipate from food packaging," Food Control, vol. 27, no. 1, pp.132-138.

Fent, K., Weston, A.A. \& Caminada, D., 2006, "Ecotoxicology of human pharmaceuticals", Aquatic Toxicology, vol. 76, no. 2, pp. 122-159.

Ferrando-Climent, L., Collado, N., Buttiglieri, G., Gros, M., Rodriguez-Roda, I., Rodriguez-Mozaz, S. \& Barceló, D., 2012, "Comprehensive study of ibuprofen and its metabolites in activated sludge batch experiments and aquatic environment", Science of The Total Environment, vol. 438, no. 0 , pp. 404-413.

Fisher, M.M. \& Eugster, E.A., 2014, "What is in our environment that effects puberty?," Reproductive Toxicology, vol. 44, pp. 7-14.

Focazio, M.J., Kolpin, D.W., Barnes, K.K., Furlong, E.T., Meyer, M.T., Zaugg, S.D., Barber, L.B. \& Thurman, M.E., 2008, "A national reconnaissance for pharmaceuticals and other organic wastewater contaminants in the United States-II) Untreated drinking water sources", Science of the Total Environment, vol. 402, no. 2, pp. 201-216.

García, S.O., Pinto, G.P., Encina, P.G. and Mata, R.I., 2013. Consumption and occurrence of pharmaceutical and personal care products in the aquatic environment in Spain. Science of the Total Environment, 444, pp.451-465.

García-Galán, M.J., González Blanco, S., López Roldán, R., Díaz-Cruz, S. \& Barceló, D., 2012, "Ecotoxicity evaluation and removal of sulfonamides and their acetylated metabolites during conventional wastewater treatment", Science of The Total Environment, vol. 437, no. 0, pp. 403412.

Giokas, D.L., Salvador, A., \& Chisvert, A., 2007, "UV filters: from sunscreens to human body and the environment", Trends in Analytical Chemistry, vol. 26, pp. 360-374.

Gordalla, B.C., Ewers, U. \& Frimmel, F.H., 2013, "Hydraulic fracturing: a toxicological threat for groundwater and drinking-water?", Environmental Earth Sciences, vol. 70, no. 8, pp. 3875-3893.

Gregg, T., Prahl, F.G. and Simoneit, B.R., 2015, "Suspended particulate matter transport of polycyclic aromatic hydrocarbons in the lower Columbia River and its estuary," Limnology and Oceanography, vol. 60, no. 6, pp.1935-1949.

Grignard, E., Lapenna, S. \& Bremer, S., 2012, "Weak estrogenic transcriptional activities of Bisphenol A and Bisphenol S", Toxicology in Vitro, vol. 26, no. 5, pp. 727-731. 
Guerra, P., Kim, M., Shah, A., Alaee, M. and Smyth, S.A., 2014. Occurrence and fate of antibiotic, analgesic/anti-inflammatory, and antifungal compounds in five wastewater treatment processes. Science of the Total Environment, vol. 473, pp.235-243.

Hayes, T., Haston, K., Tsui, M., Hoang, A., Haeffele, C. \& Vonk, A., 2003, "Atrazine-induced hermaphroditism at $0.1 \mathrm{ppb}$ in American leopard frogs (Rana pipiens): laboratory and field evidence", Environmental Health Perspectives, vol. 111, no. 4, pp. 568-575.

Hayes, T.B., Collins, A., Lee, M., Mendoza, M., Noriega, N., Stuart, A.A. \& Vonk, A., 2002, "Hermaphroditic, demasculinized frogs after exposure to the herbicide atrazine at low ecologically relevant doses", Proceedings of the National Academy of Sciences of the United States of America, vol. 99, no. 8, pp. 5476-5480.

Heberer, T., 2002, "Occurrence, fate, and removal of pharmaceutical residues in the aquatic environment: a review of recent research data", Toxicology Letters, vol. 131, no. 1, pp. 5-17.

Hirai, H., Takada, H., Ogata, Y., Yamashita, R., Mizukawa, K., Saha, M., Kwan, C., Moore, C., Gray, H. \& Laursen, D., 2011, "Organic micropollutants in marine plastics debris from the open ocean and remote and urban beaches", Marine Pollution Bulletin, vol. 62, no. 8, pp. 1683-1692.

Hirani, Z.M., Bukhari, Z., Oppenheimer, J., Jjemba, P., LeChevallier, M.W. \& Jacangelo, J.G., 2013, "Characterization of effluent water qualities from satellite membrane bioreactor facilities", Water Research, vol. 47, no. 14, pp. 5065-5075.

Hong P, Al-Jassim N, Ansari MI, and Mackie RI., 2013, "Environmental and public health implications of water reuse: Antibiotics, antibiotic resistant bacteria, and antibiotic resistance genes," Antibiotics, vol. 2, no. 3, pp. 367-99.

Huschek, G., Hansen, P.D., Maurer, H.H., Krengel, D. \& Kayser, A. 2004, "Environmental risk assessment of medicinal products for human use according to European Commission recommendations", Environmental Toxicology, vol. 19, no. 3, pp. 226-240.

Ikehata, K., Gamal El-Din, M. and Snyder, S.A., 2008, "Ozonation and advanced oxidation treatment of emerging organic pollutants in water and wastewater," Ozone: Science and Engineering, vol. 30 , no. 1 , pp. 21-26.

Inoue, K., Okada, F., Ito, R., Kato, S., Sasaki, S., Nakajima, S., Uno, A., Saijo, Y., Sata, F. \& Yoshimura, Y. 2004, "Perfluorooctane sulfonate (PFOS) and related perfluorinated compounds in human maternal and cord blood samples: assessment of PFOS exposure in a susceptible population during pregnancy", Environmental Health Perspectives, Vol. 112, no. 11, pp. 1204-1207.

Jahan, K., Ordóñez, R., Ramachandran, R., Balzer, S. \& Stern, M. 2008, "Modeling biodegradation of nonylphenol", Water, Air and Soil Pollution: Focus, vol. 8, no. 3-4, pp. 395-404.

Jasper, J.T. and Sedlak, D.L., 2013, "Phototransformation of wastewater-derived trace organic contaminants in open-water unit process treatment wetlands," Environmental Science \& Technology, vol. 47, no. 19, pp. 10781-10790.

Jelić, A., Petrović, M. \& Barceló, D. 2012, "Pharmaceuticals in drinking water" in Emerging Organic Contaminants and Human Health, Springer, pp. 47-70.

Jelić, A., Gros, M., Ginebreda, A., Cespedes-Sánchez, R., Ventura, F., Petrovic, M. \& Barcelo, D. 2011, "Occurrence, partition and removal of pharmaceuticals in sewage water and sludge during wastewater treatment", Water Research, vol. 45, no. 3, pp. 1165-1176.

Jiang, L., Hu, X., Xu, T., Zhang, H., Sheng, D., \& Yin, D. 2013. Prevalence of antibiotic resistance genes and their relationship with antibiotics in the Huangpu River and the drinking water sources, Shanghai, China. Science of the Total Environment, 458, 267-272.

Jjemba, P.K. 2006, "Excretion and ecotoxicity of pharmaceutical and personal care products in the environment", Ecotoxicology and Environmental Safety, vol. 63, no. 1, pp. 113-130.

Jones, O., Voulvoulis, N. \& Lester, J. 2002, "Aquatic environmental assessment of the top 25 English prescription pharmaceuticals", Water Research, vol. 36, no. 20, pp. 5013-5022.

Kasprzyk-Hordern, B., Dinsdale, R.M. \& Guwy, A.J. 2008, "The occurrence of pharmaceuticals, personal care products, endocrine disruptors and illicit drugs in surface water in South Wales, UK", Water Research, vol. 42, no. 13, pp. 3498-3518. 
Kasprzyk-Hordern B, Dinsdale RM and Guwy AJ., 2009, "The removal of pharmaceuticals, personal care products, endocrine disruptors and illicit drugs during wastewater treatment and its impact on the quality of receiving waters", Water Research, vol. 43, pp. 363-80.

Kim JW, Jang HS, Kim JG, Ishibashi H, Hirano M, Nasu K, 2009, "Occurrence of pharmaceu- tical and personal care products (PPCPs) in surface water from Mankyung River, South Korea", Journal of Health Sciences, vol. 55, pp. 249-58.

Kolpin, D.W., Furlong, E.T., Meyer, M.T., Thurman, E.M., Zaugg, S.D., Barber, L.B. \& Buxton, H.T. 2002, "Pharmaceuticals, hormones, and other organic wastewater contaminants in US streams, 1999-2000: A national reconnaissance", Environmental Science \& Technology, vol. 36, no. 6, pp. $1202-1211$.

Kumar, V., Johnson, A.C., Nakada, N., Yamashita, N. and Tanaka, H., 2012, "De-conjugation behavior of conjugated estrogens in the raw sewage, activated sludge and river water," Journal of Hazardous Materials, vol. 227, pp.49-54.

Kümmerer, K. 2009, "Antibiotics in the aquatic environment - A review - Part I", Chemosphere, vol. 75, no. 4, pp. 417-434.

Lang, I.A., Galloway, T.S., Scarlett, A., Henley, W.E., Depledge, M., Wallace, R.B. \& Melzer, D. 2008, "Association of urinary bisphenol A concentration with medical disorders and laboratory abnormalities in adults", Jama, vol. 300, no. 11, pp. 1303-1310.

Latch, D.E., Stender, B.L., Packer, J.L., Arnold, W.A. and McNeill, K., 2003a, "Photochemical fate of pharmaceuticals in the environment: cimetidine and ranitidine," Environmental Science \& Technology, vol. 37, no.15, pp. 3342-3350.

Latch, D.E., Packer, J.L., Arnold, W.A. and McNeill, K., 2003b, "Photochemical conversion of triclosan to 2, 8-dichlorodibenzo-p-dioxin in aqueous solution," Journal of Photochemistry and Photobiology A: Chemistry, vol. 158, no. 1, pp. 63-66.

Lee, I., Lee, S. \& Oh, J. 2010, "Occurrence and fate of synthetic musk compounds in water environment", Water Research, vol. 44, no. 1, pp. 214-222.

Li, W.C., 2014, "Occurrence, sources and fate of pharmaceuticals in aquatic environment and soil", Environmental Pollution, vol. 187, pp. 193-201.

Llorca, M., Farré, M., Picó, Y., Müller, J., Knepper, T.P. and Barceló, D., 2012. Analysis of perfluoroalkyl substances in waters from Germany and Spain. Science of the total environment, 431, pp.139-150.

Liu X, Zhang J, Yin J, Duan H, Wu Y, Shao B., 2010, "Analysis of hormone antagonists in clinical and municipal wastewater by isotopic dilution liquid chromatography tandem mass spectrometry", Analytical and Bioanalytical Chemistry, vol. 396, no. 8, pp. 2977-85.

Lindqvist, N., Tuhkanen, T. \& Kronberg, L. 2005, "Occurrence of acidic pharmaceuticals in raw and treated sewages and in receiving waters", Water Research, vol. 39, no. 11, pp. 2219-2228.

López-Serna, R., Jurado, A., Vázquez-Suñé, E., Carrera, J., Petrović, M. \& Barceló, D. 2013, "Occurrence of 95 pharmaceuticals and transformation products in urban groundwaters underlying the metropolis of Barcelona, Spain", Environmental Pollution, vol. 174, no. 0, pp. 305315.

Lorber, M., Schecter, A., Paepke, O., Shropshire, W., Christensen, K., \& Birnbaum, L. 2015, "Exposure assessment of adult intake of bisphenol A (BPA) with emphasis on canned food dietary exposures," Environment international, vol. 77, pp. 55-62.

Luo, Y., Xu, L., Rysz, M., Wang, Y., Zhang, H. \& Alvarez, P.J. 2011, "Occurrence and transport of tetracycline, sulfonamide, quinolone, and macrolide antibiotics in the Haihe River Basin, China", Environmental Science \& Technology, vol. 45, no. 5, pp. 1827-1833.

Luo, Y., Guo, W., Ngo, H. H., Nghiem, L. D., Hai, F. I., Zhang, J., \& Wang, X. C., 2014, “A review on the occurrence of micropollutants in the aquatic environment and their fate and removal during wastewater treatment", Science of the Total Environment, vol. 473, pp. 619-641. 
Mahmoud, M.A., Kärrman, A., Oono, S., Harada, K.H. \& Koizumi, A. 2009, "Polyfluorinated telomers in precipitation and surface water in an urban area of Japan", Chemosphere, vol. 74, no. 3, pp. 467-472.

Maia, J., Cruz, J.M., Sendón, R., Bustos, J., Sanchez, J.J. \& Paseiro, P. 2009, "Effect of detergents in the release of bisphenol A from polycarbonate baby bottles", Food Research International, vol. 42, no. 10 , pp. $1410-1414$.

Martinez, J.L. 2009, "Environmental pollution by antibiotics and by antibiotic resistance determinants", Environmental Pollution, vol. 157, no. 11, pp. 2893-2902.

Mato, Y., Isobe, T., Takada, H., Kanehiro, H., Ohtake, C. \& Kaminuma, T. 2001, "Plastic resin pellets as a transport medium for toxic chemicals in the marine environment", Environmental Science \& Technology, vol. 35, no. 2, pp. 318-324.

Maurer, M., Escher, B.I., Richle, P., Schaffner, C. \& Alder, A.C. 2007, "Elimination of $\beta$-blockers in sewage treatment plants", Water Research, vol. 41, no. 7, pp. 1614-1622.

McClellan, K. \& Halden, R.U. 2010, "Pharmaceuticals and personal care products in archived US biosolids from the 2001 EPA national sewage sludge survey", Water Research, vol. 44, no. 2, pp. 658-668.

Meesters, R.J.W and Schroder, H.F., 2002, "Simultaneous determination of 4-nonylphenol and bisphenol A in sewage sludge," Analytical Chemistry, vol. 74, pp. 3566-3574.

Melia, P.M., Cundy, A.B., Sohi, S.P., Hooda, P.S. and Busquets, R., 2017. Trends in the recovery of phosphorus in bioavailable forms from wastewater. Chemosphere, vol. 186, pp. 381-395.

Merchant Research and Consulting, 2015, "Bisphenol A (BPA): 2015 World Market Outlook and Forecast up to 2019", [Strategic Report-PDF], Market Publishers Report Database, ID: B6B1814C5BBEN, Available at: $<$ https://marketpublishers.com/report/industry/chemicals_petrochemicals/bisphenol_a_world_ market_outlook_n_forecast.html>.

Metcalfe, C.D., Koenig, B.G., Bennie, D.T., Servos, M., Ternes, T.A. \& Hirsch, R. 2003, "Occurrence of neutral and acidic drugs in the effluents of Canadian sewage treatment plants", Environmental Toxicology and Chemistry, vol. 22, no. 12, pp. 2872-2880.

Microbead-Free Waters Act of 2015, HR 1321, H. Rept. 114-371 (2015).

Mohle, E., Kempter, C., Kern, A. \& Metzger, J. 1999, "Examination of the degradation of drugs in municipal sewage plants using liquid chromatography-electrospray mass spectrometry", Acta Hydrochimica et Hydrobiologica, vol. 27, no. 6, pp. 430-436.

Moldovan Z., 2006, "Occurrences of pharmaceutical and personal care products as micropollu- tants in rivers from Romania", Chemosphere, vol. 64, no. 11, pp. 1808-17.

Moriwaki, H., Takata, Y. \& Arakawa, R. 2003, "Concentrations of perfluorooctane sulfonate (PFOS) and perfluorooctanoic acid (PFOA) in vacuum cleaner dust collected in Japanese homes", Journal of Environmental Monitoring, vol. 5, no. 5, pp. 753-757.

Musolff, A., Leschik, S., Möder, M., Strauch, G., Reinstorf, F. \& Schirmer, M. 2009, "Temporal and spatial patterns of micropollutants in urban receiving waters", Environmental Pollution, vol. 157, no. 11, pp. 3069-3077.

National Association of Clean Water Agencies 2012, Pharmaceuticals in the water environment [Homepage of National Association of Clean Water Agencies], [Online]. Available: <http://www.dcwater.com/waterquality/PharmaceuticalsNACWA.pdf> [2013, 10 June].

National Oceanic and Atmospheric Administration 2016, "Can marine debris degrade on its own in the environment?" National Ocean Service, [online], available at: <

http://oceanservice.noaa.gov/facts/degrade.html >, Last Accessed: 27 Sept. 2016.

Nikolaou, A., Meric, S. \& Fatta, D. 2007, "Occurrence patterns of pharmaceuticals in water and wastewater environments", Analytical and Bioanalytical Chemistry, vol. 387, no. 4, pp. 12251234. 
Olsen, G.W., Chang, S., Noker, P.E., Gorman, G.S., Ehresman, D.J., Lieder, P.H. \& Butenhoff, J.L. 2009, "A comparison of the pharmacokinetics of perfluorobutanesulfonate (PFBS) in rats, monkeys, and humans", Toxicology, vol. 256, no. 1, pp. 65-74.

Oono, S., Harada, K.H., Mahmoud, M.A.M., Inoue, K. \& Koizumi, A. 2008, "Current levels of airborne polyfluorinated telomers in Japan", Chemosphere, vol. 73, no. 6, pp. 932-937.

Osenbrück, K., Gläser, H., Knöller, K., Weise, S.M., Möder, M., Wennrich, R., Schirmer, M., Reinstorf, F., Busch, W. \& Strauch, G. 2007, "Sources and transport of selected organic micropollutants in urban groundwater underlying the city of Halle (Saale), Germany", Water Research, vol. 41, no. 15, pp. 3259-3270.

Packer, J.L., Werner, J.J., Latch, D.E., McNeill, K. and Arnold, W.A., 2003, "Photochemical fate of pharmaceuticals in the environment: Naproxen, diclofenac, clofibric acid, and ibuprofen," Aquatic Sciences, vol. 65, no. 4, pp. 342-351.

Parrott, J. L., and Blunt, B. R. (2005). Life-cycle exposure of fathead minnows (Pimephales promelas) to an ethinylestradiol concentration below $1 \mathrm{ng} / \mathrm{L}$ reduces egg fertilization success and demasculinizes males. Environmental Toxicology, 20(2), 131141.

Patisaul, H.B. \& Adewale, H.B. 2009, "Long-term effects of environmental endocrine disruptors on reproductive physiology and behavior", Frontiers in Behavioral Neuroscience, vol. 3, pp. 10.

Patrolecco, L., Capri, S., De Angelis, S., Pagnotta, R., Polesello, S. \& Valsecchi, S. 2006, "Partition of nonylphenol and related compounds among different aquatic compartments in Tiber River (Central Italy)", Water, Air and Soil Pollution, vol. 172, no. 1-4, pp. 151-166.

Peck, A. 2006, "Analytical methods for the determination of persistent ingredients of personal care products in environmental matrices", Analytical and Bioanalytical Chemistry, vol. 386, no. 4, pp. 907-939.

Peng, X., Yu, Y., Tang, C., Tan, J., Huang, Q. and Wang, Z., 2008. Occurrence of steroid estrogens, endocrine-disrupting phenols, and acid pharmaceutical residues in urban riverine water of the Pearl River Delta, South China. Science of the total environment, 397(1), pp.158-166.

Pereira, V.J., Linden, K.G. and Weinberg, H.S., 2007, "Evaluation of UV irradiation for photolytic and oxidative degradation of pharmaceutical compounds in water," Water Research, vol. 41, no. 19, pp. 4413-4423.

Petrie, B., Barden, R., Kasprzyk-Hordern, B., 2015. A review on emerging contami- nants in wastewaters and the environment: current knowledge, understudied areas and recommendations for future monitoring. Water Res. 72, 3-27.

Possatto, F.E., Barletta, M., Costa, M.F., 2011, "Plastic debris ingestion by marine catfish: An unexpected fisheries impact. Marine Pollution Bulletin, vol. 62, pp. 1098-1102.

Radjenović, J., Petrović, M. \& Barceló, D. 2009, "Fate and distribution of pharmaceuticals in wastewater and sewage sludge of the conventional activated sludge (CAS) and advanced membrane bioreactor (MBR) treatment", Water Research, vol. 43, no. 3, pp. 831-841.

Raghav, M., Eden, S., Katharine, M. \& Witte, B. 2013, Contaminants of emerging concern in water, Water Resources Research Center, Tucson, USA.

Relić, D., Popović, A., Đorđević, D. and Čáslavský, J., 2017. Occurrence of synthetic musk compounds in surface, underground, waste and processed water samples in Belgrade, Serbia. Environmental Earth Sciences, 76(3), p.122.

Remberger, M., Wiklund, P., Woldegiorgis, A., Viktor, T., Kaj, L. \& Brorström-Lundén, E. 2008, "Antiinflammatory and analgesic drugs in WWTP influent and effluent streams and the occurrence in the aquatic environment", IVL Swedish Environmental Institute, Report.

Remucal, C.K., 2014, "The role of indirect photochemical degradation in the environmental fate of pesticides: a review," Environmental Science: Processes \& Impacts, vol. 16, no. 4, pp. 628-653.

Richard, C. and Canonica, S., 2005, Aquatic phototransformation of organic contaminants induced by coloured dissolved natural organic matter, In Environmental Photochemistry Part II. Springer: Berlin Heidelberg, pp. 299-323. 
Rios, L.M., Moore, C. \& Jones, P.R. 2007, "Persistent organic pollutants carried by synthetic polymers in the ocean environment", Marine Pollution Bulletin, vol. 54, no. 8, pp. 1230-1237.

Roberts, P.H. \& Thomas, K.V. 2006, "The occurrence of selected pharmaceuticals in wastewater effluent and surface waters of the lower Tyne catchment", Science of the Total Environment, vol. 356, no. 1, pp. 143-153.

Rochman, C.M., 2016, "The Role of Plastic Debris as Another Source of Hazardous Chemicals in Lower-Trophic Level Organisms," The Handbook of Environmental Chemistry, Springer Berlin Heidelberg, DOI: 10.1007/698_2016_17.

Rodil, R., Quintana, J.B., López-Mahía, P., Muniategui-Lorenzo, S., Prada-Rodríguez, D., 2008, "Multiclass determination of sunscreen chemicals in water samples by liquid chromatographytandem mass spectrometry", Analytical Chemistry, vol. 80, pp. 1307-1315.

Rodil, R., Quintana, J. B., Concha-Graña, E., López-Mahía, P., Muniategui-Lorenzo, S., \& PradaRodríguez, D. 2012, "Emerging pollutants in sewage, surface and drinking water in Galicia (NW Spain)", Chemosphere, vol. 86, no. 10, pp. 1040-1049.

Roosens, L., Covaci, A. \& Neels, H. 2007, "Concentrations of synthetic musk compounds in personal care and sanitation products and human exposure profiles through dermal application", Chemosphere, vol. 69, no. 10, pp. 1540-1547.

Rosi-Marshall, E. J., Snow, D., Bartelt-Hunt, S. L., Paspalof, A., \& Tank, J. L., 2015. A review of ecological effects and environmental fate of illicit drugs in aquatic ecosystems. Journal of Hazardous Materials, 282, 18-25.

Rudel, R.A., Perovich, L.J., 2009, "Endocrine disrupting chemicals in indoor and outdoor air," Atmospheric Environment, vol. 43, pp. 170-181.

Rudel, R.A., Camann, D.E., Spengler, J.D., Korn, L.R. \& Brody, J.G. 2003, "Phthalates, alkylphenols, pesticides, polybrominated diphenyl ethers, and other endocrine-disrupting compounds in indoor air and dust", Environmental Science \& Technology, vol. 37, no. 20, pp. 4543-4553.

Ruggeri, G., Ghigo, G., Maurino, V., Minero, C. and Vione, D., 2013, "Photochemical transformation of ibuprofen into harmful 4-isobutylacetophenone: pathways, kinetics, and significance for surface waters," Water Research, vol. 47, no. 16, pp. 6109-6121.

Saito, I., Onuki, A., Seto, H., 2004, "Indoor air pollution by alkylphenols in Tokyo", Indoor Air, vol. 14, pp. 325-332.

Salapasidou, M., Samara, C., Voutsa, D., 2011, "Endocrine disrupting compounds in the atmosphere of the urban area of Thessaloniki, Greece", Atmospheric Environment, vol. 45, pp. 3720-3729.

Salgueiro-González, N., Lopez de Alda, M., Muniategui-Lorenzo, S., Prada-Rodriguez, D., \& Barcelo, D., 2013, "Determination of 13 estrogenic endocrine disrupting compounds in atmospheric particulate matter by pressurised liquid extraction and liquid chromatography-tandem mass spectrometry," Analytical and Bioanalytical Chemistry, vol. 405, pp. 8913-8923.

Salgueiro-González, N., Lopez de Alda, M., Muniategui-Lorenzo, S., Prada-Rodríguez, D., \& Barceló, D. 2015, "Analysis and occurrence of endocrine-disrupting chemicals in airborne particles", TrAC Trends in Analytical Chemistry, vol. 66, pp. 45-52.

Sánchez-Avila, J., Meyer, J., \& Lacorte, S., 2010, "Spatial distribution and sources of perfluorochemicals in the NW Mediterranean coastal waters (Catalonia, Spain)", Environmental Pollution, vol. 158, no. 9, pp. 2833-2840.

Schultz, M.M., Higgins, C.P., Huset, C.A., Luthy, R.G., Barofsky, D.F. \& Field, J.A. 2006, "Fluorochemical mass flows in a municipal wastewater treatment facility", Environmental Science \& Technology, vol. 40, no. 23, pp. 7350-7357.

Silva, B.F.d., Jelic, A., López-Serna, R., Mozeto, A.A., Petrovic, M. \& Barceló, D. 2011, "Occurrence and distribution of pharmaceuticals in surface water, suspended solids and sediments of the Ebro river basin, Spain", Chemosphere, vol. 85, no. 8, pp. 1331-1339.

Skutlarek, D., Exner, M. \& Farber, H. 2006, "Perfluorinated surfactants in surface and drinking waters", Environmental science and Pollution Research International, vol. 13, no. 5, pp. 299. 
Stackelberg, P.E., Furlong, E.T., Meyer, M.T., Zaugg, S.D., Henderson, A.K. \& Reissman, D.B. 2004, "Persistence of pharmaceutical compounds and other organic wastewater contaminants in a conventional drinking-water-treatment plant", Science of the Total Environment, vol. 329, no. 1, pp. 99-113.

Stockholm Convention on Persistent Organic Pollutants, 2010, Guide to alternatives to perfluorooctane sulfonate and its derivatives, [pdf], (last accessed 1 May 2017), available at: <http://chm.pops.int/TheConvention/POPsReviewCommittee/Meetings/POPRC8/MeetingDocum ents/tabid/2801/ctl/Download/mid/9135/Default.aspx?id=29\&ObjlD=14868>.

Sun, M., Arevalo, E., Strynar, M., Lindstrom, A., Richardson, M., Kearns, B., Pickett, A., Smith, C. and Knappe, D.R., 2016. Legacy and emerging perfluoroalkyl substances are important drinking water contaminants in the Cape Fear River Watershed of North Carolina. Environmental Science \& Technology Letters, 3(12), pp.415-419.

ter Laak, T. L., van der Aa, M., Houtman, C. J., Stoks, P. G., \& van Wezel, A. P. 2010, "Relating environmental concentrations of pharmaceuticals to consumption: a mass balance approach for the river Rhine", Environment International, vol. 36, no. 5, pp. 403-409.

Ternes, T.A. 1998, "Occurrence of drugs in German sewage treatment plants and rivers", Water Research, vol. 32, no. 11, pp. 3245-3260.

Testai, E., Scenihr, M.S.C., Hartemann, P., Rodríguez-Farre, E., Rastogi, S.C., Bustos, J., GundertRemy, U., Hensten, A., Kopperud, H.M., Olea, N. \& Piersma, A. 2016, "The safety of the use of bisphenol A in medical devices," Regulatory Toxicology and Pharmacology, IN PRESS, doi: doi:10.1016/j.yrtph.2016.01.014.

Teuten, E.L., Saquing, J.M., Knappe, D.R., Barlaz, M.A., Jonsson, S., Bjorn, A., Rowland, S.J., Thompson, R.C., Galloway, T.S., Yamashita, R., Ochi, D., Watanuki, Y., Moore, C., Viet, P.H., Tana, T.S., Prudente, M., Boonyatumanond, R., Zakaria, M.P., Akkhavong, K., Ogata, Y., Hirai, H., Iwasa, S., Mizukawa, K., Hagino, Y., Imamura, A., Saha, M. \& Takada, H. 2009, "Transport and release of chemicals from plastics to the environment and to wildlife", Philosophical transactions of the Royal Society of London.Series B, Biological Sciences, vol. 364, no. 1526, pp. 2027-2045.

Thomas, K.V. \& Hilton, M.J. 2004, "The occurrence of selected human pharmaceutical compounds in UK estuaries", Marine Pollution Bulletin, vol. 49, no. 5, pp. 436-444.

Tijani, J.O., Fatoba, O.O., Babajide, O.O. and Petrik, L.F., 2016. Pharmaceuticals, endocrine disruptors, personal care products, nanomaterials and perfluorinated pollutants: a review. Environmental Chemistry Letters, 14(1), pp.27-49.

United States Environmental Protection Agency 2009, Targeted National Sewage Sludge Survey Statistical Analysis Report, [pdf], (last accessed 6 May 2016), available at: <http://www.epa.gov/sites/production/files/201504/documents/tnsss_stat_anal_report_revised_april_2009.pdf>.

United States Environmental Protection Agency 2012, 14 September-last update, Water: Sewage sludge (biosolids) [Homepage of USEPA], [Online]. Available: <http://water.epa.gov/polwaste/wastewater/treatment/biosolids/genqa.cfm> [2014, 27 June].

United States Environmental Protection Agency 2014, Bisphenol A alternatives in thermal paper final report, [pdf], (last accessed 3 Nov. 2015), available at:< http://www2.epa.gov/sites/production/files/2014-05/documents/bpa_final.pdf>.

United States Environmental Protection Agency 2017, PFOA stewardship program baseline year summary report, [online], (last accessed 1 May 2017), available at: $<$ https://www.epa.gov/assessing-and-managing-chemicals-under-tsca/pfoa-stewardshipprogram-baseline-year-summary-report>.

United States Geological Survey 2016, 6 May-last update, Emerging contaminants in the environment [Homepage of U.S. Department of the Interior], [Online]. Available: <http://toxics.usgs.gov/regional/emc/> [2016, 18 April]. 
Upton, R.A., Buskin, J.N., Williams, R.L., Holford, N.H.G. \& Riegelman, S. 1980, "Negligible excretion of unchanged ketoprofen, naproxen, and probenecid in urine", Journal of Pharmaceutical Sciences, vol. 69, no. 11, pp. 1254-1257.

Vajda, A.M., Barber, L.B., Gray, J.L., Lopez, E.M., Woodling, J.D. \& Norris, D.O. 2008, "Reproductive disruption in fish downstream from an estrogenic wastewater effluent", Environmental Science \& Technology, vol. 42, no. 9, pp. 3407-3414.

Van Stempvoort, D. R., Roy, J. W., Grabuski, J., Brown, S. J., Bickerton, G., \& Sverko, E., 2013, “An artificial sweetener and pharmaceutical compounds as co-tracers of urban wastewater in groundwater", Science of The Total Environment, vol. 461, pp. 348-359.

Vieno, N., Tuhkanen, T. \& Kronberg, L. 2007, "Elimination of pharmaceuticals in sewage treatment plants in Finland", Water Research, vol. 41, no. 5, pp. 1001-1012.

Vieno, N.M., Tuhkanen, T. \& Kronberg, L. 2005, "Seasonal variation in the occurrence of pharmaceuticals in effluents from a sewage treatment plant and in the recipient water", Environmental science \& Technology, vol. 39, no. 21, pp. 8220-8226.

Vulliet, E. and Cren-Olivé, C. 2011, "Screening of pharmaceuticals and hormones at the regional scale, in surface and groundwaters intended to human consumption", Environmental Pollution, vol. 159, pp. 2929-34.

Walters, E., McClellan, K. \& Halden, R.U. 2010, "Occurrence and loss over three years of 72 pharmaceuticals and personal care products from biosolids-soil mixtures in outdoor mesocosms", Water Research, vol. 44, no. 20, pp. 6011-6020.

Wang, J.L. and Xu, L.J., 2012, "Advanced oxidation processes for wastewater treatment: formation of hydroxyl radical and application," Critical reviews in environmental science and technology, vol. 42, no. 3, pp. 251-325.

Wegner, A., Besseling, E., Foekema, E., Kamermans, P. \& Koelmans, A. 2012, "Effects of nanopolystyrene on the feeding behavior of the blue mussel (Mytilus edulis L.)", Environmental Toxicology and Chemistry, vol. 31, no. 11, pp. 2490-2497.

Waste Minimisation Act of 2008. Public Act 2008 No. 89. New Zealand Parliamentary Council Office, 2008.

Weigel, S., Berger, U., Jensen, E., Kallenborn, R., Thoresen, H. \& Hühnerfuss, H. 2004, "Determination of selected pharmaceuticals and caffeine in sewage and seawater from Troms $\varnothing /$ Norway with emphasis on ibuprofen and its metabolites", Chemosphere, vol. 56, no. 6, pp. 583-592.

Wilkinson, J. L., Hooda, P. S., Barker, J., Barton, S., \& Swinden, J., 2016a, "Ecotoxic pharmaceuticals, personal care products and other emerging contaminants: A review of environmental, receptormediated, developmental, and epigenetic toxicity with discussion of proposed toxicity to human," Critical Reviews in Environmental Science and Technology, vol. 46, no. 4, pp. 336-381.

Wilkinson, J.L., Swinden, J., Hooda, P.S., Barker, J. and Barton, S., 2016b, "Markers of anthropogenic contamination: A validated method for quantification of pharmaceuticals, illicit drug metabolites, perfluorinated compounds, and plasticisers in sewage treatment effluent and rain runoff," Chemosphere, vol. 159, pp.638-646.

Wilkinson, J.L., Hooda, P.S., Swinden, J., Barker, J. and Barton, S., 2017. Spatial distribution of organic contaminants in three rivers of Southern England bound to suspended particulate material and dissolved in water. Science of The Total Environment, 593, pp.487-497.

Winkler, M., Lawrence, J.R. \& Neu, T.R. 2001, "Selective degradation of ibuprofen and clofibric acid in two model river biofilm systems", Water Research, vol. 35, no. 13, pp. 3197-3205.

Wols, B.A. and Hofman-Caris, C.H.M., 2012, "Review of photochemical reaction constants of organic micropollutants required for UV advanced oxidation processes in water," Water Research, vol. 46, no. 9, pp. 2815-2827.

Woodall, L. C., Sanchez-Vidal, A., Canals, M., Paterson, G. L., Coppock, R., Sleight, V., Calafat, A., Rogers, A.D., Narayanaswamy, B.E. \& Thompson, R. C. 2014, "The deep sea is a major sink for microplastic debris", Royal Society Open Science, vol. 1, no. 4, doi: 140317. 
Wu, C., Liu, X., Wei, D., Fan, J. and Wang, L., 2001, "Photosonochemical degradation of phenol in water," Water Research, vol. 35, no. 16, pp. 3927-3933.

Yamazaki, E., Yamashita, N., Taniyasu, S., Lam, J., Lam, P.K., Moon, H.B., Jeong, Y., Kannan, P., Achyuthan, H., Munuswamy, N. and Kannan, K., 2015, "Bisphenol A and other bisphenol analogues including BPS and BPF in surface water samples from Japan, China, Korea and India," Ecotoxicology and Environmental Safety, vol. 122, pp.565-572.

Yang, Y., Lu, L., Zhang, J., Yang, Y., Wu, Y., \& Shao, B. 2014, "Simultaneous determination of seven bisphenols in environmental water and solid samples by liquid chromatography-electrospray tandem mass spectrometry", Journal of Chromatography A, vol. 1328, pp. 26-34.

Yin J, Shao B, Zhang J, Li K., 2010, 'A preliminary study on the occurrence of cytostatic drugs in hospital effluents in Beijing, China," Bulletin of Environmental Contamination and Toxicology, vol. 84, pp. 39-45.

Zafeiraki, E., Costopoulou, D., Vassiliadou, I., Leondiadis, L., Dassenakis, E., Traag, W., Hoogenboom, R.L. and van Leeuwen, S.P., 2015, "Determination of perfluoroalkylated substances (PFASs) in drinking water from the Netherlands and Greece," Food Additives \& Contaminants: Part A, vol. 32, no. 12, pp. 2048-2057.

Zounkova, R., Kovalova, L., Blaha, L. \& Dott, W. 2010, "Ecotoxicity and genotoxicity assessment of cytotoxic antineoplastic drugs and their metabolites", Chemosphere, vol. 81, no. 2, pp. 253-260.

Zushi, Y. and Masunaga, S., 2009, "Identifying the nonpoint source of perfluorinated compounds using a geographic information system based approach", Environmental Toxicology and Chemistry, vol. 28, no. 4, pp. 691-700. 